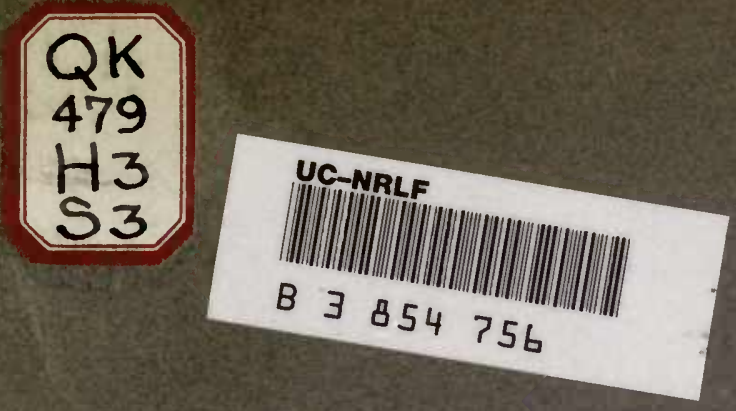

THE TIRET EIFTY YEARS OF THE

$$
\begin{aligned}
& \text { ARIOII ARBORTTHil - } \\
& \text { by } \\
& \text { C.S. Sereent }
\end{aligned}
$$

Reprint from Journal of the Amola Arboretum

$$
\text { Vol. III. }
$$




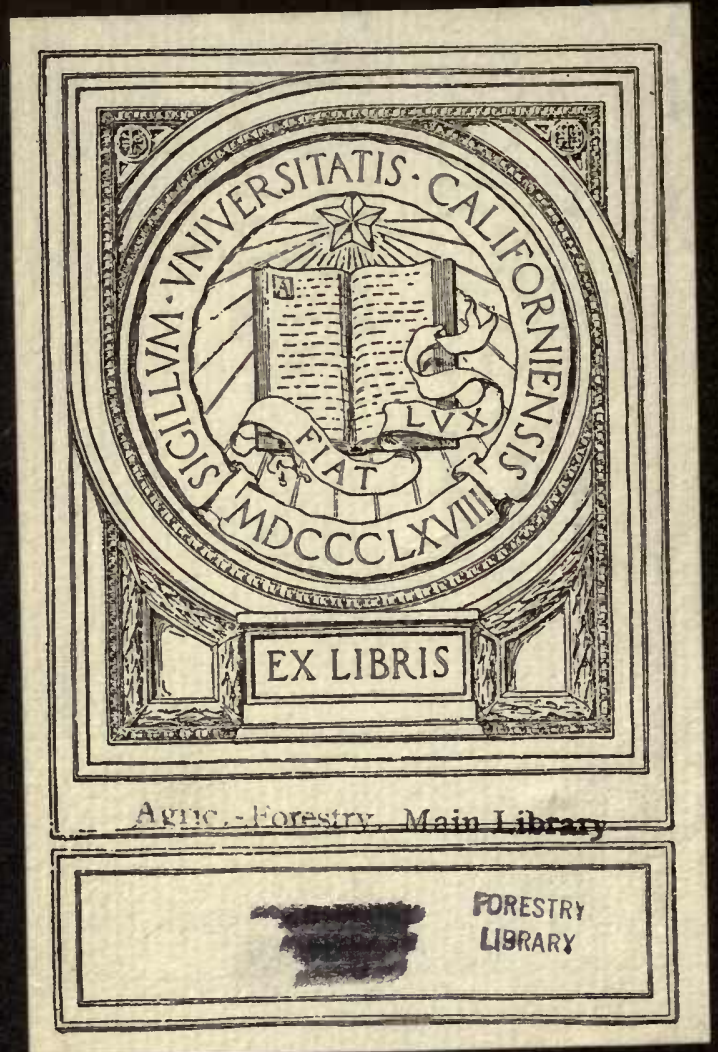




\section{Emanuel Frite.}

\section{THE FIRST FIFTY YEARS OF THE ARNOLD ARBORETUM}

\section{S. SARGENT}

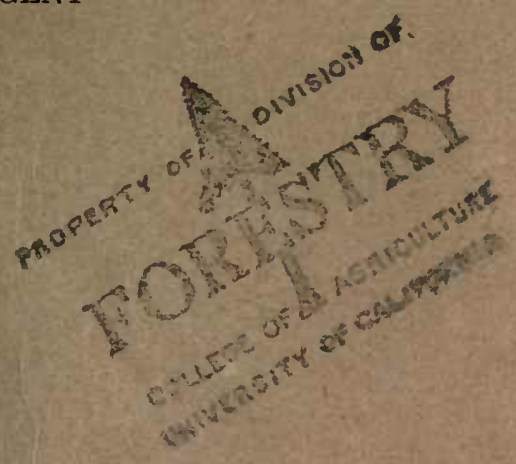

Reprinted without change of paging from Journal of the Arnold Arboretum, Vol. III. 1922 


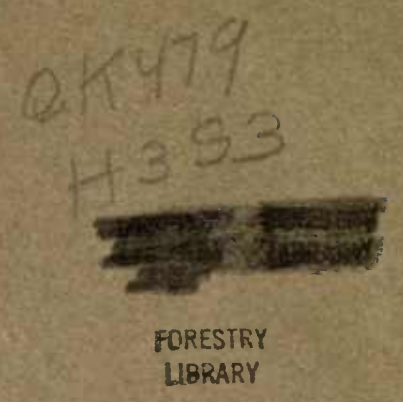

Aqric.-Forestr. Main Libran

\section{CONTENTS}

The First Fifty Years of the Arnold Arboretum. By C. S. Sargent. .................... 127 


\section{JOURNAL \\ OF THE \\ ARNOLD ARBORETUM}

\section{THE FIRST FIFTY YEARS OF THE ARNOLD ARBORETUM}

C. S. SARGENT

By his will signed on the 22d of May, 1868, James Arnold, a merchant of New Bedford, Massachusetts, gave one and one-quarter of the twentyfour parts into which he divided his residuary estate "To George B. Emerson, John James Dixwell and Francis E. Parker Esqrs. of Boston in trust: to be by them applied for the promotion of Agricultural, or Horticultural improvements, or other Philosophical, or Philanthropic purposes at their discretion, and to provide for the continuance of this Trust hereafter to such persons, and on such conditions as they, or a majority of them, may deem proper, to carry out the intention of the donor."

The senior of these Trustees, Mr. George B. Emerson, a distinguished Boston schoolmaster, had long been interested in Natural History, especially in trees, and had prepared for the Commonwealth a report on "The Trees and Shrubs growing naturally in the Forests of Massachusetts" published in 1846 and an authoritative work on the subject still consulted by students of trees. Mr. Dixwell, the second of these Trustees, a successful Boston business man, was also a lover and student of trees, and had assembled on his place in Jamaica Plain one of the largest and best collections of native and foreign trees which was growing at this time in New England. Mr. Francis E. Parker, a Boston lawyer, was also one of the Trustees under Mr. Arnold's will. Two therefore of the three men appointed by Mr. Arnold to administer his bequest for the improvement of Agriculture or Horticulture were interested in trees and understood the importance to the world of more knowledge in regard to them than could at that time be obtained in this country; and it was natural that the idea of a scientific station for the study and cultivation of trees should have occurred to them. They fortunately realized that such an institution could be permanently and safely controlled by Harvard College.

Mr. Arnold died December 3d, 1869; and on March 29, 1872, the Trustees under his will and the President and Fellows of Harvard College signed an indenture which contained the following provisions:

"That, Whereas, the said James Arnold, by his last will, devised and 
bequeathed to the said party of the first part one and a quarter twentyfourth parts of the residue of his estate 'in trust, to be by them applied for the promotion of agricultural or horticultural improvements, or other philosophical or philanthropic purposes at their discretion, and to provide for the continuance of this trust hereafter to such persons, and on such conditions as they or a majority of them may deem proper to carry out the intention of the donor'; and

"Whereas, Benjamin Bussey, late of Roxbury, in the county of Norfolk, merchant, deceased, by his last will and testament devised to the said party of the second part an estate in remainder subject to certain life estates in the estate on which he had lived in said Roxbury, called 'Woodland Hill,' consisting of over two hundred acres of land, in trust and confidence that they would "establish there a course of instruction in practical agriculture, in useful and ornamental gardening, in botany, and in such branches of natural science as may tend to promote a knowledge of practical agriculture and the various arts subservient thereto and connected therewith, and cause such courses of lectures to be delivered there, at such seasons of the year and under such regulations as they may think best adapted to promote the ends designed,- the institution so established to be called the 'Bussey Institution'; and

"Whereas, the said party of the first part have agreed and determined, in the exercise of the discretion given them under the will of the said James Arnold, that the disposition of the property devised and bequeathed to them as aforesaid, in the manner and for the purposes and upon the conditions hereinafter set forth, is and will be the most suitable and proper execution of their trust, and will most effectually provide for the continuance of the trust for the future, to carry out the intention of the donor,

"Now, Therefore, it is agreed, bargained, and covenanted by and between the said party of the first part and the said party of the second part, as follows:-

"First. The said Emerson, Dixwell, and Parker, trustees, party of the first part, in consideration of the covenants, agreements, and undertakings of the said President and Fellows hereinafter set forth, do hereby give, grant, bargain, sell, convey, assign, and transfer to the said President and Fellows of Harvard College, party of the second part, and their assigns forever, the whole property and estate devised and bequeathed to them, the party of the first part, under and by virtue of the will of the said James Arnold, which has been already received or shall be hereafter received by the said party of the first part (excepting and reserving therefrom a sum sufficient to pay the actual expenses incurred by said party of the first part), a schedule of which, so far as received, is hereto annexed,-

"To Have and to Hold the same to the said party of the second part, and their assigns forever, in trust, with full power of sale and reinvestment, upon the trusts following, namely,

"That the said party of the second part shall hold the same as a separate 
and distinct fund, and shall allow the whole net income thereof (after deducting the necessary expenses of managing the same, and also deducting, if they see fit, one third part of such net income in each year as is hereinafter provided) to accumulate and add the same to the principal, until the said fund shall amount, at a just valuation, to one hundred and fifty thousand dollars, and until the land at West Roxbury hereinafter described shall come into the possession of the said party of the second part as an estate in possession, free of all life tenancies or other encumbrances.

"Second. When both said events shall have happened, that the said party of the second part shall accumulate five per centum of the said net income, in every year, and add the same to the capital, as a part of the said permanent and separate trust fund.

"Third. That the said party of the second part shall devote the remainder of the said net income in every year to the establishment and support of an Arboretum, to be called the

\section{Arnold Arboretum,}

which shall contain, as far as is practicable, all the trees, shrubs, and herbaceous plants, either indigenous or exotic, which can be raised in the open air at the said West Roxbury, all which shall be raised or collected as fast as is practicable, and each specimen thereof shall be distinctly labelled, and to the support of a professor, to be called the Arnold Professor, who shall have the care and management of the said Arboretum, subject to the same control by the said President and Fellows to which the professors in the Bussey Institution are now subject, and who shall teach the knowledge of trees in the University which is in the charge of the said President and Fellows, and shall give such other instruction therein as may be naturally, directly, and usefully connected therewith. And as the entire fund, increased by the accumulations above named, under the best management and with the greatest economy, is barely sufficient to accomplish the proposed object, it is expressly provided that it shall not be diminished by supplementing any other object, however meritorious or kindred in its nature.

But the said President and Fellows shall be allowed to obtain from said Arboretum, free of cost, any trees, shrubs, and herbaceous plants, which, in the judgment of the Arnold Professor, can be spared from said Arboretum without injury thereto, the same to be used for the ornament of the College grounds, at Cambridge or elsewhere.

Fourth. Until the happening of both of the events named in the first clause, the said party of the second part may expend one third part of said net income in every year, and no more, in such preparation of the land hereinafter named, and in such collecting or raising of specimens, and the necessary superintendence thereof, as will promote the general and ultimate purpose above stated, but in no other way." 
By this indenture Harvard College received as an Endowment for the proposed Arboretum $\$ 103,847.57$ and agreed to use for it about one hundred and twenty-five acres of its Bussey estate. The land devoted at this time to the Arboretum had a frontage on Centre Street from the position of the present Centre Street entrance for about half the distance to the corner of Walter Street, on South Street from a point a short distance east of the present South Street entrance to the corner of Bussey Street, and for about three-quarters the length of the last named street. The northern boundary crossed the north meadow about where the group of Phellodendrons now stands on the right hand side of the Meadow Road, and was often covered with water from the brook from Centre Street which discharged its water on the undrained surface of the meadow. The low land near the junction of the Meadow, Forest Hills and Bussey Hill Roads, now partly occupied by the three small ponds, was an undrained swamp. Hemlock Hill was then perhaps more beautiful than it is now for since that time several old White Pine-trees which were then in their prime and rose high above the Hemlocks have died. The valley of Bussey Brook at the northern base of Hemlock Hill was then covered by an almost impenetrable thicket of Alders, and the western boundary of the proposed Arboretum crossed the brook a little west of the present grove of Red Pines. There was no access to these one hundred and twenty-five acres except by a steep cart track from the entrance to the Bussey Mansion across land controlled by the Bussey Institution.

I was appointed Director of the new Arboretum by the President and Fellows of the College on November 24, 1873. The prospect of being able to establish a useful institution would not have been encouraging if the men interested in it had had at that time as much knowledge as hope and enthusiasm. For it is safe to say that not one of them had an idea of what an Arboretum might be, or what it was going to cost in time and money to carry out the provisions of the indenture between the Trustees under Mr. Arnold's will and the President and Fellows of Harvard College; and certainly not one of them was more ignorant of the subject than the man selected to carry out the provisions of this agreement. He found himself with a worn-out farm, partly covered with natural plantations of native trees nearly ruined by excessive pasturage, to be developed into a scientific garden with less than three thousand dollars a year available for the purpose. He was without equipment or the support and encouragement of the general public which then knew nothing about an Arboretum and what it was expected to accomplish. The work of forming a nursery, however, was begun at once, greenhouses of the Bussey Institution being available for the propagation of the few plants which could at that time be found in the neighborhood of Boston.

In $1873 \mathrm{Mr}$. Frederick Law Olmsted was engaged in planning and constructing a park system for the City of Boston and suggested that that part of the Bussey farm which was to be devoted to the Arboretum might 
be used with certain restrictions as one of the Boston parks. The suggestion met with little favor and was opposed by the governing Board of the College and by the Park Commissioners of Boston. The press was indifferent, and its only enthusiastic supporters were $\mathbf{M r}$. Olmsted and the Director of the Arboretum, and several years of hard semipolitical work were needed to make possible Mr. Olmsted's plan. On December 30, 1882, however, the consent of the Legislature to it having been obtained, the following agreement between the City of Boston through its Park Commission and the President and Fellows of Harvard College was signed:

"Whereas the Board of Park Commissioners of the City of Boston by virtue of the authority conferred upon said Board by chapter one hundred and eighty-five of the Acts of the Legislature of Massachusetts of the year 1875 and by the City Council of said City of Boston, by a certain written instrument of even date herewith to be recorded with the Suffolk Registry of Deeds have taken and located as and for a public park that tract of land in that part of said City known as West Roxbury held by the College and by it dedicated to the use of the Arnold Arboretum, so called, together with certain adjoining tracts, the property of other persons deemed by said Commissioners convenient and necessary for use in connection therewith for the purposes and under the powers and limitations set forth in said act and acts in addition thereto and amendment thereof - And whereas by an act of the General Court of Massachusetts passed on the twentyninth day of March in the year 1880 it was enacted that in case the said Board of Park Commissioners deemed it desirable so to take the said lands for the said purposes the City was thereby authorized to lease such portion of the said Arboretum and adjoining tracts so taken as the said Board of Commissioners might deem not necessary for use as parkways and grounds to the College to be held to the same uses and purposes as the said Arboretum was then held under the trusts created by the wills of Benjamin Bussey and of James Arnold and for such a term and upon such mutual restrictions, reservations, covenants and conditions as to the use thereof by the public in connection with the uses of the same under the said trusts, and as to the rights, duties and obligations of the contracting parties as might be agreed upon between the said Commissioners and the College. And the Board of Park Commissioners on the part of the City and the President on behalf of the College were respectively authorized to execute and deliver the said lease. And whereas the said Board of Park Commissioners deems such portion of the said Arboretum and adjoining tracts as is hereinafter described and leased to be not necessary for use as parkways and grounds and considers that the same will be better and more advantageously enjoyed and used by the public as a part of the said park if the same be leased to the College for the purposes of the said trusts and upon such terms and subject to such provisions with regard to the use thereof by the public as are hereinafter contained. And it has been agreed between the said Commissioners and the College that the same be 
leased to the College for the term and upon the mutual restrictions, reservations, covenants and conditions hereinafter expressed.

"Now this Indenture witnesseth that the City by virtue and in exercise of the power and authority given to it by the said Act and of every other power and authority it hereto enabling doth demise and lease unto the College all that parcel of land delineated on a plan entitled 'The Arnold Arboretum' and to be recorded herewith in the Suffolk Registry of Deeds situate in that part of Boston known as West Roxbury and bounded and described as follows:-

"Excepting and always reserving out of these presents all those parts of the said lands delineated and marked on the said plan as driveways and parkways and those parts of the same lands delineated and marked $A$ and $B$ respectively on the said plan. And granting with the premises hereby leased a free and unobstructed right of way upon and over all the said excepted parts of the said lands and upon and over the driveways and parkways delineated on the said plan and so marked thereon.

"To have and to hold the premises hereby leased (hereinafter called the Arnold Arboretum) unto the College and its successors and assigns for the term of One thousand years from the date hereof without impeachment of waste upon and for the same trusts, uses and purposes as those upon and for which the said land held by the College for the purposes of the said Arboretum at the said time of the passing of the said Act of the year 1880 was then held under the will of Benjamin Bussey and the will of James Arnold and a certain indenture dated the 29th day of March in the year 1872 and made between George B. Emerson, John J. Dixwell and Francis E. Parker as Trustees of the will of the said James Arnold of the one part and the College of the other part in which indenture the trusts provided for in the said will of James Arnold are declared in pursuance of the directions in the said will contained. Yielding and paying therefor during the said term the yearly rent of one dollar - And the City covenants with the College and its successors and assigns that the College and its successors and assigns shall peaceably hold and enjoy the premises hereby leased during the said term without any interference or control of the City or any person claiming through or under it. That the City will at all times save and keep harmless and indemnified the College and its successors and assigns and keep the premises hereby leased free and discharged of and from all taxes and assessments of every description which during the said term may be assessed or payable in respect of or charged upon the premises hereby leased or any part thereof. That the City will within a reasonable time make and finish fit for use of good sound materials and in a proper and workmanlike manner the driveways of which the sites and dimensions are delineated on the said plan and so marked thereon but at a cost not exceeding seventy-five thousand dollars, and that the said driveways during the said term shall be repaired and maintained in a 
proper and substantial manner free of all charge and expense to the College and its successors and assigns. That the City will during the said term provide and maintain a proper and sufficient police in and about the Arnold Arboretum and the said parts excepted from these presents and the said roads, avenues, and parkways for the preservation of order and good conduct and the observance of the rules hereinafter mentioned or provided for. That no public street or highway and no steam or horse railway or construction for like purposes shall be laid out through or over any part of the Arnold Arboretum except in such places, if any, and in such manner as the Park Commissioners and the College shall approve. That if the water supply from the sources within the Arnold Arboretum which the College has heretofore enjoyed for use in the said Arboretum shall at any time be cut off, interrupted or impaired by the City or its assigns the City will immediately provide at its own charge and expense an equal or superior supply of water for the like use. And that if the College, its successors or assigns shall be desirous of taking a renewed lease of the said premises for the further term of One thousand years from the expiration of the term hereby granted the City or its assigns will upon the request and at the expense of the College, its successors or assigns and upon its or their executing and delivering to the City or its assigns a counterpart thereof forthwith execute and deliver to the College, its successors or assigns a renewed lease of the said premises for the further term of One thousand years at the same yearly rent and upon and subject to the same restrictions, reservations, covenants, and conditions as are herein contained including this present covenant and so on from time to time forever. And the College for itself and its successors and assigns covenants with the City that the College will not commence or prosecute any action, suit or other proceeding against the City for the enforcement or recovery of any damages or claim which the College may have or be entitled to against the City by reason of the said taking of the said Arboretum land by the City. And that the Arnold Arboretum shall at all reasonable times be open to the inspection of the public as a part of the said Park subject to the rules hereinafter mentioned or provided for. Provided, Always, and it is hereby declared that the City shall be at liberty to erect and maintain suitable gateways for entrance thereto upon any of the said excepted parts and to maintain gates there. And that no pavilion, kiosk, urinal, museum, greenhouse, stable, shed, or other building (except as above provided) shall be erected or maintained within the Arnold Arboretum or in any of the said excepted parts or in any of the said driveways or parkways without the prior consent of the Park Commissioners and the College. Provided, also, and it is hereby declared and agreed that the use of the Arnold Arboretum and of the said excepted parts and of the said roads, avenues and parkways by the City and its assigns and the College, its successors and assigns and the public shall be subject to the rules contained in the schedule hereto annexed and to 
such additional rules as have been or may from time to time be agreed upon between the Park Commissioners and the College. But any of the said rules may be altered or annulled by agreement between the Park Commissioners and the College."

By this agreement the location of the Arboretum was practically fixed for at least one thousand years, for although the College may in the future wish to move it to less valuable land it is not possible to conceive that the City of Boston will ever consent to abandon the benefit it derives from the use of the Arboretum as a public park. By this agreement the Arboretum is relieved of the danger of taxation during the period of the lease and obtains without expense the protection of the Boston police. In return for these benefits the public is admitted to the free enjoyment of a public garden maintained with the exception of the roads by the University. By this arrangement more than two-thirds of the north meadow. with the land on which the Administration Building now stands and the hill behind it was added to the original area of the Arboretum, which also gained an entrance from Walter Street and that part of the valley of the Bussey Brook between Walter Street and the western boundary of the Bussey Farm. In return the Arboretum gave up to the City the land now occupied by the Arborway between the old northern boundary of the north meadow and the Forest Hills entrance and the wooded slope east of the Arborway.

A few trees along the boundaries had been planted before 1882, but the City was slow in building the roads with their adjoining gravel paths, and it was not possible to begin planting trees in systematic arrangement until 1885, that is at the end of thirteen years devoted to preliminary negotiations and the perfection of plans.

It was soon found that the area which in 1882 was devoted to the Arboretum was inadequate for the purpose, and that if even a small part of the trees and shrubs which the College had arranged with $\mathrm{Mr}$. Arnold's Trustees was to be found in it more land was needed for the purpose. Two estates on Centre Street with an area of about eight acres between the original western boundary of the Bussey Farm at this point and Walter Street were bought by the City for the Arboretum and the buildings were removed from them. In 1894 the President and Fellows of the College transferred their property west of Bussey Street, with an area of seventy-five acres and known as Peter's Hill, to the Arboretum. The arrangement made in 1882 with the City of Boston for the ownership and control of the original Arboretum was extended to the Peter's Hill addition. In $1904 \mathrm{a}$ few friends of the Arboretum bought for it a house and about four thousand feet of land on Centre Street between Pince and Orchard Streets, Jamaica Plain, near the entrance of that name. The house is used as the home for the superintendent, and the grounds attached to it as a nursery. For many years the propagation of plants for the Arboretum had been carried on on a small piece of ground near 
the Centre Street entrance, leased from the Trustees of the Adams Nervine Asylum for the purpose, and to take the place of these inadequate accommodations a modern greenhouse with cold pits and frames was built in 1917 on the Centre Street land for a new propagating plant. In 1919 the land of the Bussey Institution between South Street and the location of the Dedham Branch of the N. Y. N. H. \& H. R. R. with an area of sixteen acres was bought for it by friends of the Arboretum from the College; and in 1922 the hill surrounded by property belonging to the Park Department of Boston, and by Centre and Walter Streets and an unnamed road connecting these streets, with an area of fourteen acres, has also been bought by friends of the Arboretum and presented to it. The persent area of the Arboretum is now therefore approximately two hundred and fifty acres.

\section{NATURAL FEATURES}

Meadows, hills and valleys are found within the boundaries of the Arboretum. The ground rises gradually from the great meadow at its north end to the summit of Bussey Hill from which views of the Blue Hills to the south and of Cambridge and Boston are obtained. From the top of Bussey Hill the ground drops abruptly to South Street on the south and to the west and southwest to the valley which extends from Centre to South Streets, and which at the northern base of the second of the Arboretum hills, Hemlock Hill, is joined nearly at right angles by the valley through which Bussey Brook flows from the northwest and enters the Arboretum under Walter Street. Through the valley which separates the western base of Hemlock Hill from the third and highest of the Arboretum hills, Peter's Hill, Bussey Street, a highway open to traffic, extends from Walter Street at a point near the Walter Street entrance to the Arboretum to South Street, and separates Peter's Hill from the rest of the Arboretum. The land acquired in 1919 between South Street and the railroad drops abruptly at its eastern end from the southern base of Bussey Hill to a broad low peat meadow through which a new channel for the Bussey Brook has been made; west of this low meadow only a narrow strip of higher land separates South Street from the railroad. A hill sloping to the north and east on Centre Street and separated by a low depression from the base of a slope descending from Walter Street and facing the north is the feature of the latest addition to the Arboretum area.

The great natural feature of the Arboretum is Hemlock Hill with its high steep cliffs rising on the north from the Bussey Brook and covered so thickly with Hemlock trees that the rays of the sun rarely penetrate to the ground between them. In no other public garden are there such cliffs or a more beautiful remnant of a coniferous forest. Oaks and other native deciduous leaved trees from one hundred to perhaps two hundred years old still cover small areas on each side of the Meadow Road, 
on Centre Street, and on Bussey Street at the eastern base of Peter's Hill, and are valuable in showing several important New England trees in their adult state.

\section{ARRANGEMENT OF THE LIVING PLANTS}

The trees which have been planted are arranged in botanical sequence in family groups, the genera of each family and the species of each genus being placed together, the arrangement beginning with the Magnolia Family at the Jamaica Plain Gate and ending with the Pinaceae at the Walter Street Gate.

That they may show their habit under different conditions several individuals of important North American species have been planted close together in groups, and at a distance from the group an individual of the species is planted with sufficient space about it to insure a full development of branches. A representative of almost every genus stands near a drive so that visitors passing along the Arboretum roads and gravel paths can obtain an idea of the genera of trees hardy in Massachusetts and of their relation to each other. An attempt has been made to place the Family groups in positions where the trees may find favorable conditions for growth without interfering with the beauty of hills and valleys, and of the natural woods. Access to the different groups of all the trees is secured by grass-covered paths several miles in length which reach every part of the Arboretum and make easy the examination of the trees. Hardy shrubs of genera in which there are not species which are trees are arranged in the same sequence as the trees in parallel beds ten feet wide with a total length of $\mathbf{7 7 6 5}$ feet, and separated by grass-covered paths. This shrub collection is situated on the level ground near the Forest Hills entrance and is surrounded by a trellis on which are grown vines and other climbing plants. It has been established for the instruction of gardeners, landscape gardeners and others interested in shrubs who can find in it all the perfectly hardy species of many genera conveniently arranged for comparative study. Insufficient space in the area devoted to this shrub collection has made it necessary to arrange the shrubs belonging to genera in which some of the species are trees in groups as near as possible to the trees of the same genus or Family; as, for example, the Spindle-trees (Evonymus) and the Sumachs (Rhus) on opposite sides of the Meadow Road, the Lilacs below the Ash-trees on the left hand side of the Bussey Road, the Viburnums near the junction of the Bussey and Valley Roads, and the Kalmias and Rhododendrons at the base of Hemlock Hill. Large numbers of shrubs have also been planted to form margins to the roads and an undergrowth among the groups of trees, native shrubs having been chiefly used for this purpose in order to preserve as far as possible a New England character. Peter's Hill has been used for an extension of the Pinetum, for the principal collection of Hawthorns which occupies its eastern slope, for a large supplementary collection of Crabapples and species 
of Pear-trees, and the collection of Poplars and Alders; below the top of the hill and near the western boundary of the Arboretum is a large mixed plantation of deciduous-leaved trees in which are found some of the rarest and most interesting species in the whole collection, for this exposed hilltop has proved favorable to the growth of several trees which have not flourished in the Arboretum at lower levels. The land between South Street and the railroad will be used for new and enlarged collections of Poplars and Willows, and the addition between Centre and Walter will be chiefly planted with trees which require deep soil and good drainage to enable them to grow to a large size and live to old age.

The regions represented by the living collections are the cool temperate and colder parts of North America, Europe and Asia, including the higher altitudes of the Himalayas and other more southern mountains. No plants from the southern hemisphere, not even from the high Andes, southern Chile or the higher mountains of New Zealand have proved hardy in the Arboretum. It is believed that there are now growing in the Arboretum between five and six thousand species and varieties of trees and shrubs which belong to the following Families and Genera:

\section{GYMNOSPERMAE}

Ginkgo

Ginkgoaceae

Taxaceae

Cephalotaxus

Taxus

Torreya

Pinaceae

Abies

Cedrus

Chamaecyparis

Cryptomeria

Cupressus
Larix

Libocedrus

Picea

Pinus

Pseudolarix

Pseudotsuga

Sciadopitys

Taxodium

Thuja -

Tsuga

Gnetaceae
Ephedra

ANGIOSPERMAE

MONOCOTYLEDONEAE

\section{Gramineae}

Arundinaria

Phyllostachys

Sasa

\author{
Liliaceae \\ Smilax \\ Yucca
}

\section{DICOTYLEDONEAE}

Salicaceae

Populus

Salix
Myricaceae

Comptonia

Myrica 
Leitneriaceae

Leitneria

Carya

Juglandaceae

Juglans

Platycarya

Pterocarya

Betulaceae

Alnus

Betula

Carpinus

Corylus

Ostrya

Ostryopsis

Castanea

\section{Fagaceae}

Fagus

Quercus

Ulmaceae

Celtis

Hemiptelea

Pteroceltis

Ulmus

Zelkova

Moraceae

Maclura

Morus

Aristolochiaceae

Aristolochia

Polygonaceae

Atraphaxis

Chenopodiaceae

Atriplex

Eurotia

Trochodendraceae

Euptelea

Cercidiphyllaceae

Cercidiphyllum

\section{Ranunculaceae}

Clematis

Paeonia

Zanthorrhiza
Lardizabalaceae

Akebia

Decaisnea

Sargentodoxa

- Berberidaceae

Berberis

$\times$ Mahoberberis

Mahonia

Menispermaceae

Cocculus

Menispermum

Sinomenium

Magnoliaceae

Liriodendron

Magnolia

Schisandra

Calycanthaceae

Calycanthus

Anonaceae

Asimina

Lauraceae

Benzoin

Sassafras

Cruciferae

Aethionema

Alyssum

Iberis

Saxifragaceae

Decumaria

Deutzia

Fendlera

Hydrangea

Itea

Jamesia

Philadelphus

Ribes

Schizophragma

Whipplea

Hamamelidaceae

Corylopsis

Fortunearia

Fothergilla

Hamamelis 
Liquidambar

Parrotia

Parrotiopsis

Sinowilsonia

\section{Eucommiaceae}

Eucommia

\section{Platanaceae}

Platanus

\section{Rosaceae}

Amelanchier

Cercocarpus

Chaenomeles

Chamaebatiaria

Cotoneaster

$X$ Crataegomespilus

Crataegus

Cydonia

Dryas

Exochorda

Holodiscus

Kerria

Maddenia

Malus

Mespilus

Neillia

Neviusa

Osmaronia

Pentactina

Peraphyllum

Petrophytum

Photinia

Physocarpus

Potentilla

Prinsepia

Prunus

Pyracantha

Pyrus

Rhodotypus

Rosa

Rubus

Sibiraea

Sorbaria

$\times$ Sorbaronia

XSorbopyrus
Sorbus

Spiraea

Stephanandra

Stranvaesia

Leguminosae

Amorpha

Calophaca

Campylotropis

Caragana

Cercis

Cladrastis

Colutea

Coronilla

Cytisus

Desmodium

Genista

Gleditsia

Gymnocladus

Halimodendron

Hedysarum

Indigofera

$\times$ Laburnocytisus

Laburnum

Lespedeza

Maackia

Petteria

Robinia

Sophora

Ulex

Wistaria

Evodia

Orixa

Phellodendron

Poncirus

Ptelea

Ruta

Zanthoxylum

Simarubaceae

Ailanthus

Picrasma

Cedrela

Meliaceae 
Polygalaceae

Polygala

Euphorbiaceae

Andrachne

Daphniphyllum

Securinega

Buxus

Pachysandra

Sarcococca

Corema

Empetraceae

Empetrum

Coriariaceae

Coriaria

Anarcardiaceae

Cotinus

Rhus

Aquifoliaceae

Ilex

Nemopanthes

Celastraceae

Celastrus

Evonymus

Pachystima

Tripterygium

Staphyleaceae

Staphylea

Aceraceae

Acer

Hippocastanaceae

Aesculus

Sapindaceae

Koelreuteria

Sapindus

Xanthoceras

\section{Sabiaceae}

Meliosma

Sabia

Rhamnaceae

Berchemia

Ceanothus
Hovenia

Paliurus

Rhamnella

Rhamnus

Sageretia

Zizyphus

Vitaceae

Ampelopsis

Cissus

Columella

Parthenocissus

Vitis

Tiliaceae

Grewia

Tilia

Malvaceae

Hibiscus

Sphaeralcea

Dilleniaceae

Actinidia

Theaceae

Gordonia

Stewartia

Guttiferae

Hypericum

Tamaricaceae

Myricaria

Tamarix

Cistaceae

Helianthemum

Hudsonia

Stachyuraceae

Stachyurus

Cactaceae

Opuntia

Thymelaeaceae

Daphne

Dirca

Wikstroemia

Elaeagnaceae

Elaeagnus

Hippophae

Shepherdia 


\section{Lythraceae}

Decodon

Nyssaceae

Davidia

Nyssa

Araliaceae

Acanthopanax

Aralia

Echinopanax

Hedera

Cornaceae

Cornus

Helwingia

Clethraceae

Clethra

Pyrolaceae

Chimaphila

\section{Ericaceae}

Andromeda

Arctostaphylus

Arctous

Bruckenthalia

Calluna

Cassiope

Chamaedaphne

Chiogenes

Daboecia

Enkianthus

Epigaea

Erica

Gaultheria

Gaylussacia

Kalmia

Ledum

Leiophyllum

Leucothoe

Loiseleuria

Lyonia

Menziesia

Oxydendron

Phyllodoce

Pieris

Rhododendron

Tripetaleia
Tsusiophyllum

Vaccinium

Zenobia

Bumelia

Ebenaceae

Diospyros

Styracaceae

Halesia

Pterostyrax

Styrax

Symplocaceae

Symplocos

Oleaceae

Chionanthus

Fontanesia

Forestiera

Forsythia

Fraxinus

Jasminum

Ligustrum

Syringa

Loganiaceae

Buddleia

Apocynaceae

Vinca

Asclepiadaceae

Marsdenia

Periploca

Boraginaceae

Ehretia

Verbenaceae

Callicarpa

Caryopteris

Clerodendron

Vitex

Labiatae

Elsholtzia

Hyssopus

Lavandula

Perowskia

Teucrium

Thymus 
Solanaceae

Lycium

Solanum

Scrophulariaceae

Paulownia

Pentstemon

Veronica

Bignoniaceae

Anisostichus

Bignonia

Catalpa

Rubiaceae

Cephalanthus

Leptodermis

Mitchella
Caprifoliaceae

Abelia

Diervilla

Dipelta

Kolkwitzia

Linnaea

Lonicera

Sambucus

Symphoricarpus

Viburnum

Compositae

Artemisia

Baccharis

Chrysanthemum

Pertya

\section{RECORDS AND LABELS}

As far as it has been possible to do it the record of every species and variety of the trees and shrubs planted in the Arboretum has been kept in a card catalogue and to each has been given a number. The exact position of each tree in the systematically arranged groups is designated on the sheets of a large-scale map and with them is kept the detailed history of each tree in the hope that it will be possible for a stranger to locate every tree in the collection even if the labels are lost.

To a branch of every important plant in the Arboretum is attached a small metal label on which the name, origin and card catalogue number of the plant is stamped with raised letters. These labels are to preserve records and not for public use. For the instruction of visitors zinc labels six inches long and four inches wide painted brown with their Latin and English names and their native country in black letters are fastened with copper nails to the trunks of large trees at about the height of the eye. Small trees and large shrubs are furnished with oblong wooden labels about eight inches long painted white with black letters and hung from a branch in a conspicuous position; metal labels of about the same size as the trunk labels and raised a few inches above the surface of the ground are placed before the plants in the general shrub collection.

\section{THE INTRODUCTION OF NEW PLANTS}

In 1872 when Harvard College agreed to obtain as far as practicable for the Arnold Arboretum all the trees, shrubs and other plants which could be grown in West Roxbury very few such plants could be found in any private or commercial collection in the United States, and a large number of them were still unknown either in this country or in a living state in 
Europe; and for more than forty years continuous efforts have been made to make it possible for Harvard to make good in its contract with $\mathbf{M r}$. Arnold's Trustees. Some progress has been made but there are still regions of the northern hemisphere to explore, and trees still unknown in Massachusetts to be brought here.

At once after his appointment the Director began to obtain plants and seeds from European botanical and horticultural establishments; and in December 1878 the Arboretum received from William S. Clark, first President of the Agricultural College at Sapporo in Japan, its first direct consignment of seeds from eastern Asia.

The first opportunity to obtain on a large scale for the Arboretum American plants not then in cultivation in the United States came in 1877 when the Director was asked to prepare for the General Government a report on the forests and forest wealth of the country. In the preparation of this report he was obliged to travel into all the forest regions of the country and to select as assistants the men living in different parts of the United States best equipped with knowledge of trees and forests. Among these assistants the Arboretum found friends who continued to help it during the remainder of their lives and to keep it in constant communication with all parts of the United States.

During the last forty years the Arboretum has lost no opportunity to increase the number of species of plants cultivated in the United States and Europe. Its officers and agents have continued to explore the forests of North America; they have visited every country in Europe, the Caucasus, eastern Siberia and Korea, and have studied every species of tree growing in the forests of the Japanese Empire from Saghalin to the mountains of Formosa. The most successful of all plant collectors, Mr. E. H. Wilson, now Assistant Director of the Arboretum, has gathered for it seeds and other material of the trees and shrubs and of the Lilies that grow in great variety on the mountains which rise from western China to the Tibetan Plateau. Agents of the Arboretum in pursuit of knowledge and material have visited the Malay Peninsula, Java, the Himalayas, the high mountains of east tropical Africa, southern Africa, Australia, Mexico, Peru, Chile southward to Terra del Fuego, and the Falkland Islands. One of the results of these journeys of the last forty years is the introduction into the United States of the plants named in the following list. Those which are preceded by a cross are hybrids, and those preceded by an asterisk are believed to have been first introduced into cultivation by the agency of the Arboretum.

*Abelia Engleriana; *A. Graebneriana; *A. longituba; *A. parvifolia; *A. Schumannii; *A. Zanderi.

*Abies chensiensis; A. concolor; A. Delavayi; A. Fargesii; *A. Faxoniana; A. grandis (hardy form from Idaho); ${ }^{* A}$. holophylla; A. homolepis var. umbellata; A. koreana; A. lasiocarpa var. Beissneri; *A. recurvata; A. sachalinensis; *A. sachalinensis var. Mayriana; *A. sachalinensis var. 
nemorensis; A. sibirica var. nephrolepis; ${ }^{*}$ A. sibirica var. nephrolepis f. chlorocarpa; A. spectabilis var. brevifolia; *A. squamata; *A. sutchuenensis; *A. Veitchii var. olivacea.

*Acanthopanax Giraldii; A. Henryi; A. innovans; *A. lasiogyne; A. leucorrhizus; *A. leucorrhizus var. fulvescens; *A. leucorrhizus var. scaberulus; A. ricinifolius; A. sciadophylloides; A. sessiliflorum var. parviceps; A. setchuenensis; A. Simonii; A. ternatus.

Acer barbinerve; A. barbinerve var. glabrescens; A. Buergerianum; A. Buergerianum var. trinerve; A. campestre var. hebecarpum; A. campestre var. nanum; *A capillipes; A. cappadocicum f. tricaudatum; A. carpinifolium; *A. catalpifolium; A. caudatum; A. caudatum var. multiserratum; *A. caudatum var. Prattii; A. caudatum var. ukurunduense; A: cissifolium; A. crataegifolium; A. Davidii; A. diabolicum var. purpurascens; A. discolor; A. distylum; A. Durettii; A. Fargesii; A. flabellatum; A. Franchetii; A. ginnala; A. ginnala var. aidzuense; A. ginnala var. Semenowii; A. grandidentatum; A. griseum; A. Heldreichii; A. Heldreichii var. macropterum; A. Henryi; ${ }^{*}$ A. Hersii; ${ }^{*}$ A. laxiflorum; A. longipes; A. mandshuricum; *A. Maximowiczii; A. Mayrii; A. micranthum; ${ }^{* A}$. Miyabei; *A. morrisonense; A. nikoense; A. Negundo (dwarf form); *A. nudicarpum; *A. Okamotoanum; A. opalus; A. opalus var. tomentosum; A. parviflorum; A. pennsylvanicum var. erythrocladum; A. pictum; A. pictum var. parviflorum; A. pictum var. tricuspe; *A. pilosum; A. platanoides var. acuminatum; A. Pseudo-Platanus var. erythrocarpum; A. pseudo-sieboldianum; A. pseudo-sieboldianum var. ambiguum; *A. pycnanthum; A.robustum; A. rufinerve; A. saccharinum (dwarf form); *A. saccharum var. Schneckii; A. Sieboldianum; A. sinense; A. tegmentosum; A. tetramerum; A. tetramerum var. betulifolium f. latialatum; *A. tetramerum var. elobulatum $\mathrm{f}$. longeracemosum; $\mathrm{A}$. tetramerum var. tiliifolium; A. Trautvetteri; *A. triflorum; A. truncatum; *A. Tschonoskii; *A. Tschonoskii var. rubripes; A. zoeschense; A. zoeschense var. elongatum. Actinidia callosa var. Henryi; A. chinensis; *A. coriacea; A. Henryi; A. melanandra; ${ }^{*}$ A. purpurea; ${ }^{*}$ A. tetramera; ${ }^{*}$ A. venosa.

*Aesculus arguta; *XA. Bushii; A. chinensis; A. discolor var. mollis; A. georgiana; *A. georgiana var. lanceolata; *A. georgiana var. pubescens; *A. glabra var. Buckleyi; *A. glabra var. leucodermis; *A. glaucescens; *XA. Harbisonii; *XA. mississippiensis; A. turbinata var. pubescens;

*A. Wilsonii.

Ailanthus altissima var. sutchuenensis; A. Vilmoriniana.

*Akebia lobata var. australis.

Alangium platanifolium.

Albizzia coreana.

Alnus cremastogyne; A. firma; A. firma var. hirtella; *A. fruticosa var. mandshurica; A. hirsuta; A. hirsuta var. sibirica; A. lanata; *A. Maximowiczii; *A. mollis; A. pendula; ${ }^{*}$ A. sinuata; A. tenuifolia. 
Amelanchier asiatica var. sinica.

Ampelopsis aconitifolia var. palmiloba; A. brevipedunculata var. citrulloides; A. Delavayana; A. humulifolia; A. megalophylla; A. micans; *A. micans var. cinerea; A. Watsoniana.

Andrachne colchica; *A. phyllanthoides.

Aphananthe aspera.

Aralia chinensis; A. chinensis var. glabrescens.

Ardisia japonica.

Aristolochia heterophylla; A. Kaempferi; A. manshuriensis; A. moupinensis.

*Artemisia cana; *A. tripartita.

*Arundinaria Murielae.

Benzoin cercidifolium; B. grandifolium; B. obtusilobum; B. praecox; *B. trilobum; *B. umbellatum var. sericeum.

*Berberis aemulans; *B. aggregata; B. aggregata var. Prattii; B. aggregata var. recurvata; B. amurensis; ${ }^{*}$ B. atrocarpa; ${ }^{*}$ B. Beaniana; ${ }^{*}$ B. Bergmanniae var. acanthophylla; *B. Boschanii; B. brachypoda; B. Bretschneideri; B. candidula; ${ }^{*}$ B. circumserrata; B. consimilis; B. dasystachya; B. diaphana; B. dictyophylla; *B. dictophylla var. epruinosa; *B. Dielsiana; *B. Francisci-Ferdinandi; B. Gagnepainii; *B. Gilgiana; ${ }^{*}$ B. Henryana; B. Julianae; *B. koreana; *B. Liechtensteinii; ${ }^{*}$ B. morrisonensis; *B. Mouillacana; ${ }^{*}$ B. Poiretii f. weichangensis; B. polyantha; *B. Purdomii; B. Rehderiana; *B. Sargentiana; *B. Sieboldii; ${ }^{*}$ B. Silva-Taroucana; B. subcaulialata; ${ }^{*}$ B. thibetica; B. Thunbergii var. Maximowiczii; *B. Thunbergii var. minor; ${ }^{*}$ B. Tischleri; ${ }^{*}$ B. triacanthophora; B. Veitchii; *B. Vernae; B. verruculosa; B. Wilsonae; B. Wilsonae var. Stapfiana; B. yunnanensis.

Berchemia volubilis.

Betula alba var. songarica; B. albo-sinensis; *B. albo-sinensis var. septentrionalis; B. chinensis; ${ }^{*} \mathrm{~B}$. coerulea; ${ }^{*} \mathrm{~B}$. coerulea var. Blanchardii; *B. corylifolia; *B. costata; B. davurica; B. Delavayi; B. Ermanii var. brevidentata; *B. Ermannii var. Saitoana; B. Ermannii var. subcordata; B. fontinalis; *B. fontinalis var. Piperi; B. grossa; B. japonica; B. japonica var. kamtschatica; B. japonica var. mandshurica; ${ }^{*} B$. japonica var. szechuanica; B. luminifera; B. mandshurica; B. Maximowicziana; B. Medwediewii; B. microphylla; B. Middendorfii; *B. neo-alaskana; B. papyrifera var. kenaica; *B. papyrifera var. subcordata; ${ }^{*}$ B. Potaninii; ${ }^{*}$ B. Sandbergii; *B. Schmidtii; B. utilis; B. utilis var. Prattii.

$\times$ Bignonia hybrida "Madame Galen".

Buddleia albiflora; B. Davidii; B. Davidii var. magnifica; * B. Davidii var. superba; B. Davidii var. Wilsonii; *B. Lindleyana var. sinuato-dentata; B. nivea; B. nivea var. yunnanensis; ${ }^{*}$ B. officinalis; ${ }^{*}$ B. stenostachya.

Buxus japonica; *B. microphylla var. koreana.

Callicarpa dichotoma; C. Giraldiana. 
Camellia cuspidata.

Camptotheca acuminata.

*Campylotropis Falconeri; C. macrocarpa.

Caragana Boisii; ${ }^{*} \mathrm{C}$. Maximowicziana; ${ }^{*} \mathrm{C}$. sukiensis.

Carpinus Betulus var. carpinizza; C. Betulus f. fastigiata; C. Betulus f. globosa; C. cordata; C. cordata var. chinensis; ${ }^{*}$ C. eximia; ${ }^{*}$ C. Fargesiana; ${ }^{*} \mathrm{C}$. Fauriei; ${ }^{*} \mathrm{C}$. Henryana; ${ }^{*} \mathrm{C}$. japonica; ${ }^{*} \mathrm{C}$. laxiflora; C. laxiflora var. macrostachya; ${ }^{*}$ C. Tschonoskii; ${ }^{*}$ C. Turczaninovii; C. Turczaninovii var. ovalifolia.

* Carrierea calycina.

${ }^{*}$ Carya alba ovoidea ${ }^{*} \times$ C. Brownii; ${ }^{*} \times$ C. Brownii var. varians; ${ }^{*} \mathrm{C}$. Buckleyi; ${ }^{*} \mathrm{C}$. Buckleyi var. arkansana; *C. Buckleyi var. arkansana f. pachylemma; ${ }^{*} \mathrm{C}$. Buckleyi var. villosa; ${ }^{*} \mathrm{C}$. carolinae-septentrionalis; ${ }^{*} \mathrm{C}$. cordiformis var. latifolia; $X^{*} \mathrm{C}$. Dunbarii; ${ }^{*} \mathrm{C}$. glabra var. megacarpa; ${ }^{*} \times$ C. Laneyi; ${ }^{*} \times$ C. Laneyii var. chateaugayensis; $\times$ C. McAllisteri; ${ }^{*} \mathrm{C}$. myristicaeformis; $\times \mathrm{C}$. Nussbaumerii; ${ }^{*} \mathrm{C}$. ovalis var. hirsuta; ${ }^{*} \mathrm{C}$. ovata var. ellipsoidalis; ${ }^{*} \mathrm{C}$. ovata var. fraxinifolia; ${ }^{*} \mathrm{C}$. pallida; ${ }^{*} \mathrm{C}$. texana.

*Cassiope selaginoides.

Castanea Henryi; C. mollissima; C. neglecta; C. Seguinii.

${ }^{*}$ Castanopsis ceratacantha; ${ }^{*} \mathrm{C}$. platyacantha; C. sclerophylla.

${ }^{*}$ Catalpa Bungei; *C. Duclouxii; *C. Fargesii.

*Cedrela microcarpa; C. sinensis.

*Cedrus libani (hardy form from the Cilician Taurus).

Celastrus angulata; C. flagellaris; ${ }^{*} \mathrm{C}$. gemmata; ${ }^{*}$ C. glaucophylla; C. Hookeri; ${ }^{*}$ C. hypoleuca; C. Loeseneri; ${ }^{*} \mathrm{C}$. Rosthorniana; ${ }^{*} \mathrm{C}$. rugosa. Celtis australis; C. Biondii; C. Bungeana; C. caucasica; ${ }^{*} \mathrm{C}$. cerasifera; C. Douglasii; C. jessoensis; ${ }^{*}$ C. Julianae; ${ }^{*}$ C. koraiensis; ${ }^{*}$ C. labilis; ${ }^{*}$ C. laevigata var. Smallii; ${ }^{*}$ C. pumila var. Deamii; C. reticulata; C. Tournefortii.

Cephalotaxus drupacea var. sinensis; ${ }^{*} \mathrm{C}$. nana.

*Ceratostigma Willmottianum.

*Cercidiphyllum japonicum var. sinense.

${ }^{*}$ Cercis racemosa.

Cercocarpus montanus.

${ }^{*}$ Chaenomeles lagenaria var. Wilsonii.

*Chamaebatiaria millefolium.

Chamaecyparis Lawsoniana var. Fletcheri; C. Lawsoniana var. lycopodioides; C. Lawsoniana var. tamariscifolia; *C. obtusa var. breviramea; ${ }^{*}$ C. obtusa var. formosana.

Chionanthus retusus.

*Chloranthus serratus.

Chrysanthemum sibiricum.

Chrysothamnus pumilus.

${ }^{*}$ Citrus ichangensis. 
${ }^{*}$ Cladrastis platycarpa; C. sinensis; ${ }^{*} \mathrm{C}$. Wilsonii.

Clematis apiifolia; ${ }^{*}$ C. apiifolia var. obtusidentata; C. Armandii; ${ }^{*} \mathrm{C}$. Armandii f. Farquhariana; ${ }^{*} \mathrm{C}$. chiisanensis; C. chinensis; C. columbiana; ${ }^{*}$ C. Delavayi; ${ }^{*}$ C. Fargesii; ${ }^{*}$ C. Fargesii var. Soulieana; C. glauca var. akebioides; ${ }^{*}$ C. glauca var. angustifolia; C. Gouriana; * G. Gouriana var. Finetii; ${ }^{*} \mathrm{C}$. gracilifolia; ${ }^{*} \mathrm{C}$. grata var. grandidentata; ${ }^{*} \mathrm{C}$. grata var. lobulata; ${ }^{*} \mathrm{C}$. heracleaefolia var. ichangensis; C. lasiandra; ${ }^{*} \mathrm{C}$. macropetala; C. montana var. rubens; C. montana var. Wilsonii; ${ }^{*}$ C. montana var. Wilsonii f. platysepala; C. paniculata var. dioscoreaefolia; ${ }^{*} \mathrm{C}$. Pavoliniana; ${ }^{*}$ C. Pierotii; ${ }^{*}$ C. Prattii; C. pterantha; C. Rehderiana; C. serratifolia; ${ }^{*}$ C. Spooneri; C. tangutica; ${ }^{*}$ C. tangutica var. obtusiuscula; C. trullifera; C. uncinata; C. Veitchiana.

${ }^{*}$ Clematoclethra actinidioides; ${ }^{*} \mathrm{C}$. integrifolia; ${ }^{*} \mathrm{C}$. lasioclada var. grandis; *C. scandens.

Clerodendron trichotomum var. Fargesii.

*Clethra monostachya; C. Fargesii.

Cocculus trilobus.

*Columella oligocarpa.

${ }^{*}$ Comanthosphace sublanceolata.

Coriaria japonica; C. sinica.

Cornus alba var. Kesselringii; C. alba var. Rosenthalii; C. Bretschneideri; C. controversa; ${ }^{*}$ C. florida f. xanthocarpa; ${ }^{*}$ C. Hemsleyi; C. Hessei; C. Koenigii; *C. koreana; C. kousa (Chinese form); C. officinalis; C. paucinervis; C. poliophylla; C. pumila; C. sanguinea var. atrosanguinea; C. sanguinea var. viridissima; C. stolonifera var. coloradensis; C. stolonifera var. flaviramea; C. Walteri.

${ }^{*}$ Corylopsis glabrescens; ${ }^{*} \mathrm{C}$. Gotoana; ${ }^{*} \mathrm{C}$. platypetala; C. sinensis; C. Veitchiana; ${ }^{*}$ C. Willmottiae.

Corylus avellana var. contorta; C. chinensis; C. heterophylla; ${ }^{*}$ C. heterophylla var. sutchuenensis; C. mandshurica; C. Sieboldiana; C. tibetica.

${ }^{*}$ Cotinus americanus.

Cotoneaster acutifolia; ${ }^{*}$ C. acutifolia var. villosula; C. adpressa; C. ambigua; C. amoena; ${ }^{*}$ C. apiculata; C. bullata var. macrophylla; C. buxifolia var. vellaea; C. Dammeri; C. Dielsiana; ${ }^{*}$ C. Dielsiana var. elegans; ${ }^{*}$ C. divaricata; ${ }^{*}$ C. foveolata; C. Franchetii; C. Henryana; C. horizontalis; C. horizontalis var. perpusilla; ${ }^{*} \mathrm{C}$. hupehensis; C. ignava; C. moupinensis; ${ }^{*} \mathrm{C}$. multiflora var. calocarpa; ${ }^{*} \mathrm{C}$. nitens; C. obscura; ${ }^{*}$ C. obscura var. cornifolia; C. racemiflora var. Veitchii; ${ }^{*}$ C. racemiflora var. microcarpa; ${ }^{*} \mathrm{C}$. racemiflora var. soongorica; ${ }^{*} \mathrm{C}$. salicifolia; ${ }^{*} \mathrm{C}$. salicifolia var. floccosa; C. salicifolia var. rugosa; C. Zabelii; ${ }^{*}$ C. Zabelii var. miniata.

$\times$ Crataegomespilus Dardari; $\times$ C. Dardari var. Asnieresii; $\times$ C. grandiflora.

${ }^{*}$ Crataegus abjecta; ${ }^{*} \mathrm{C}$. acclivis; ${ }^{*} \mathrm{C}$. acerba; ${ }^{*} \mathrm{C}$. acuminata; ${ }^{*} \mathrm{C}$. 
acutifolia; ${ }^{*} \mathrm{C}$. acutiloba; ${ }^{*} \mathrm{C}$. admiranda; ${ }^{*} \mathrm{C}$. advena; ${ }^{*} \mathrm{C}$. affinis; ${ }^{*} \mathrm{C}$. alacris; ${ }^{*} \mathrm{C}$. allecta; ${ }^{*} \mathrm{C}$. alnorum; ${ }^{*} \mathrm{C}$. ambitiosa; ${ }^{*} \mathrm{C}$. ambrosia; ${ }^{*} \mathrm{C}$. amnicola; ${ }^{*} \mathrm{C}$. amoena; ${ }^{*} \mathrm{C}$. amplifica; ${ }^{*} \mathrm{C}$. anomala; ${ }^{*} \mathrm{C}$. apiomorpha; ${ }^{*} \mathrm{C}$. apposita; ${ }^{*} \mathrm{C}$. aprica; ${ }^{*} \mathrm{C}$. aquilonaris; ${ }^{*} \mathrm{C}$. arcana; ${ }^{*} \mathrm{C}$. arcuata; ${ }^{*} \mathrm{C}$. ardua; ${ }^{*} \mathrm{C}$. arduennae; ${ }^{*} \mathrm{C}$. aridula; ${ }^{*} \mathrm{C}$. arkansana; ${ }^{*} \mathrm{C}$. arnoldiana; ${ }^{*} \mathrm{C}$. ascendens; ${ }^{*} \mathrm{C}$. aspera; ${ }^{*} \mathrm{C}$. asperata; ${ }^{*} \mathrm{C}$. asperifolia; ${ }^{*} \mathrm{C}$. assurgens; ${ }^{*} \mathrm{C}$. ater; ${ }^{*} \mathrm{C}$. atrorubens; ${ }^{*} \mathrm{C}$. attenuata; ${ }^{*} \mathrm{C}$. angustata; ${ }^{*} \mathrm{C}$. aulica; ${ }^{*} \mathrm{C}$. austera.

${ }^{*}$ Crataegus baccata; ${ }^{*}$ C. Balkwillii; C. barbara; ${ }^{*}$ C. barrettiana; ${ }^{*}$ C. Barryana; ${ }^{*}$ C. Bartoniana; C. Bartramiana; ${ }^{*}$ C. Bealii; ${ }^{*} \mathrm{C}$. beata; ${ }^{*} \mathrm{C}$. Beckiana; ${ }^{*} \mathrm{C}$. bedfordensis; ${ }^{*} \mathrm{C}$. bella; ${ }^{*} \mathrm{C}$. bellica; ${ }^{*} \mathrm{C}$. bellula; ${ }^{*} \mathrm{C}$. benigna; ${ }^{*} \mathrm{C}$. Berlandieri; ${ }^{*} \mathrm{C}$. Bicknellii; ${ }^{*} \mathrm{C}$. Bissellii; ${ }^{*} \mathrm{C}$. blairensis; ${ }^{*} \mathrm{C}$. Blanchardii; ${ }^{*} \mathrm{C}$. blanda; ${ }^{*} \mathrm{C}$. blandita; ${ }^{*} \mathrm{C}$. bona; ${ }^{*} \mathrm{C}$. Boothiana; ${ }^{*} \mathrm{C}$. brachypoda; ${ }^{*} \mathrm{C}$. bracteata; ${ }^{*} \mathrm{C}$. Brainerdii; ${ }^{*} \mathrm{C}$. brazoria; ${ }^{*} \mathrm{C}$. Brittonii; ${ }^{*} \mathrm{C}$. Brockwayae; ${ }^{*} \mathrm{C}$. Brownietta; ${ }^{*} \mathrm{C}$. Brunetiana; ${ }^{*} \mathrm{C}$. Bushii.

Crataegus caesariata; ${ }^{*} \mathrm{C}$. caesia; ${ }^{*} \mathrm{C}$. caliciglabra; ${ }^{*} \mathrm{C}$. callicarpa; ${ }^{*} \mathrm{C}$. callophylla; ${ }^{*} \mathrm{C}$. callosa; ${ }^{*} \mathrm{C}$. calvescens; ${ }^{*} \mathrm{C}$. Calvenii; ${ }^{*} \mathrm{C}$. canadensis; ${ }^{*} \mathrm{C}$. Canbyi; ${ }^{*} \mathrm{C}$. candens; ${ }^{*} \mathrm{C}$. Carrierei; C. celsa; ${ }^{*} \mathrm{C}$. cerasina; ${ }^{*} \mathrm{C}$. cestrica; ${ }^{*} \mathrm{C}$. chadsfordiana; ${ }^{*} \mathrm{C}$. champlainensis; ${ }^{*} \mathrm{C}$. Chapmanii; ${ }^{*} \mathrm{C}$. chateaugayensis; ${ }^{*} \mathrm{C}$. chippewarensis; ${ }^{*} \mathrm{C}$. Clintoniana; ${ }^{*} \mathrm{C}$. coccineata; ${ }^{*} \mathrm{C}$. coccinioides; ${ }^{*} \mathrm{C}$. coerulescens; ${ }^{*} \mathrm{C}$. cognata; ${ }^{*} \mathrm{C}$. coloradensis; ${ }^{*} \mathrm{C}$. colorado; ${ }^{*} \mathrm{C}$. colorata; ${ }^{*} \mathrm{C}$. columbiana; ${ }^{*} \mathrm{C}$. comata; ${ }^{*} \mathrm{C}$. compacta; ${ }^{*} \mathrm{C}$. comparata; ${ }^{*} \mathrm{C}$. compta; ${ }^{*} \mathrm{C}$. condensa; ${ }^{*} \mathrm{C}$. conferta; ${ }^{*} \mathrm{C}$. confinis; ${ }^{*} \mathrm{C}$. confragosa; ${ }^{*} \mathrm{C}$. congestiflora; ${ }^{*} \mathrm{C}$. conjuncta; ${ }^{*} \mathrm{C}$. conspecta; ${ }^{*} \mathrm{C}$. conspicua; ${ }^{*} \mathrm{C}$. consarta; ${ }^{*} \mathrm{C}$. contigua; ${ }^{*} \mathrm{C}$. contortifolia; ${ }^{*} \mathrm{C}$. contortula; ${ }^{*}$ C. corporea; ${ }^{*}$ C. crassifolia; ${ }^{*} \mathrm{C}$. Crawfordiana; ${ }^{*}$ C. cristata; ${ }^{*} \mathrm{C}$. cruda; ${ }^{*} \mathrm{C}$. crudilis; ${ }^{*} \mathrm{C}$. Crusgalli var. oblongifolia; ${ }^{*} \mathrm{C}$. Crus-galli var. ovalifolia; ${ }^{*} \mathrm{C}$. Crus-galli var. rubescens; ${ }^{*} \mathrm{C}$. culta; ${ }^{*} \mathrm{C}$. cuprea; ${ }^{*} \mathrm{C}$. cupulifera; ${ }^{*} \mathrm{C}$. cyanophylla.

${ }^{*}$ Crataegus dacrioidea; ${ }^{*} \mathrm{C}$. dallasiana; ${ }^{*} \mathrm{C}$. Damei; ${ }^{*} \mathrm{C}$. dasyphylla; ${ }^{*} \mathrm{C}$. Dawsoniana; ${ }^{*} \mathrm{C}$. Dayana; ${ }^{*} \mathrm{C}$. debilis; ${ }^{*} \mathrm{C}$. definata; ${ }^{*} \mathrm{C}$. delawarensis; ${ }^{*} \mathrm{C}$. delecta; ${ }^{*} \mathrm{C}$. delectabilis; ${ }^{*} \mathrm{C}$. delectata; ${ }^{*} \mathrm{C}$. deltoides; ${ }^{*} \mathrm{C}$. Delosii; ${ }^{*} \mathrm{C}$. delucida; ${ }^{*} \mathrm{C}$. demissa; ${ }^{*} \mathrm{C}$. densiflora; ${ }^{*} \mathrm{C}$. desueta; ${ }^{*} \mathrm{C}$. Deweyana; ${ }^{*} \mathrm{C}$. Dewingei; ${ }^{*} \mathrm{C}$. diaphora; ${ }^{*} \mathrm{C}$. diffusa; ${ }^{*} \mathrm{C}$. digna; ${ }^{*} \mathrm{C}$. dilatata; ${ }^{*} \mathrm{C}$. disjuncta; ${ }^{*} \mathrm{C}$. dissimilis; ${ }^{*} \mathrm{C}$. dissona; ${ }^{*} \mathrm{C}$. divergens; ${ }^{*} \mathrm{C}$. diversifolia; ${ }^{*}$ C. divida; ${ }^{*}$ C. Dodgei; ${ }^{*}$ C. Douglasii var. Suksdorfii; ${ }^{*} \mathrm{C}$. drymophila; ${ }^{*} \mathrm{C}$. dsungarica; ${ }^{*} \mathrm{C}$. dumetosa; ${ }^{*} \mathrm{C}$. dumicola; ${ }^{*} \mathrm{C}$. Dunbari; ${ }^{*} \mathrm{C}$. durobrivensis.

${ }^{*}$ Crataegus Eamesii; ${ }^{*}$ C. Eastmaniana; ${ }^{*}$ C. Eatoniana; ${ }^{*}$ C. Edsonii; ${ }^{*} \mathrm{C}$. effera; ${ }^{*}$ C. efferta; ${ }^{*}$ C. effulgens; ${ }^{*}$ C. Eganii; ${ }^{*} \mathrm{C}$. Egglestonii; ${ }^{*} \mathrm{C}$. Ellwangeriana; ${ }^{*} \mathrm{C}$. elongata; ${ }^{*} \mathrm{C}$. Emersoniana; ${ }^{*} \mathrm{C}$. Engelmannii; ${ }^{*} \mathrm{C}$. enucleata; ${ }^{*} \mathrm{C}$. erecta; ${ }^{*} \mathrm{C}$. errata; ${ }^{*} \mathrm{C}$. erythrocarpa; ${ }^{*} \mathrm{C}$. erythropoda; ${ }^{*} \mathrm{C}$. Evansiana; ${ }^{*} \mathrm{C}$. exclusa; ${ }^{*} \mathrm{C}$. exigua; ${ }^{*} \mathrm{C}$. exornata.

Crataegus fallsiana; ${ }^{*} \mathrm{C}$. Faxonii; ${ }^{*} \mathrm{C}$. fecunda; ${ }^{*} \mathrm{C}$. ferentaria; ${ }^{*} \mathrm{C}$. ferox; ${ }^{*} \mathrm{C}$. Ferrissii; ${ }^{*} \mathrm{C}$. ferta; ${ }^{*} \mathrm{C}$. fertilis; ${ }^{*} \mathrm{C}$. filipes; ${ }^{*} \mathrm{C}$. finitima; ${ }^{*} \mathrm{C}$. 
firma; ${ }^{*}$ C. flabellata; ${ }^{*}$ C. flagrans; ${ }^{*}$ C. flammea; ${ }^{*}$ C. flavida; ${ }^{*}$ C. florea; ${ }^{*} \mathrm{C}$. florifera; ${ }^{*} \mathrm{C}$. fluviatalis; ${ }^{*} \mathrm{C}$. foetida; ${ }^{*} \mathrm{C}$. foliata; ${ }^{*} \mathrm{C}$. Fontanesiana; ${ }^{*} \mathrm{C}$. Forbesae; ${ }^{*} \mathrm{C}$. formosa; ${ }^{*} \mathrm{C}$. fortunata; ${ }^{*} \mathrm{C}$. Fretzii; ${ }^{*} \mathrm{C}$. fructuosa; ${ }^{*} \mathrm{C}$. fucosa; ${ }^{*} \mathrm{C}$. fulgens; ${ }^{*} \mathrm{C}$. fulgida; ${ }^{*} \mathrm{C}$. Fulleriana; ${ }^{*} \mathrm{C}$. furcata.

${ }^{*}$ Crataegus gaudens; ${ }^{*} \mathrm{C}$. Gaultii; ${ }^{*} \mathrm{C}$. gemmosa; ${ }^{*} \mathrm{C}$. geneseensis; ${ }^{*} \mathrm{C}$. genialis; ${ }^{*} \mathrm{C}$. georgiana; ${ }^{*} \mathrm{C}$. gilva; ${ }^{*} \mathrm{C}$. glabrata; ${ }^{*} \mathrm{C}$. glabrifolia; ${ }^{*} \mathrm{C}$. glabriuscula; ${ }^{*} \mathrm{C}$. glariosa; ${ }^{*} \mathrm{C}$. glaucophylla; ${ }^{*} \mathrm{C}$. globosa; ${ }^{*} \mathrm{C}$. gloriosa; ${ }^{*} \mathrm{C}$. gracilipes; ${ }^{*} \mathrm{C}$. gratiosa; ${ }^{*} \mathrm{C}$. gravida; ${ }^{*} \mathrm{C}$. gravis; ${ }^{*} \mathrm{C}$. grignonensis; *C. Grubneri.

${ }^{*}$ Crataegus Habereri; ${ }^{*} \mathrm{C}$. Halliana; ${ }^{*} \mathrm{C}$. hamata; ${ }^{*} \mathrm{C}$. Handyae; ${ }^{*} \mathrm{C}$. Hargeri; ${ }^{*} \mathrm{C}$. heidelbergensis; ${ }^{*} \mathrm{C}$. Heldreichii; ${ }^{*} \mathrm{C}$. Helenae; ${ }^{*} \mathrm{C}$. hiemalis; ${ }^{*} \mathrm{C}$. Hillii; ${ }^{*} \mathrm{C}$. hirtella; ${ }^{*} \mathrm{C}$. hispidula; ${ }^{*} \mathrm{C}$. Holmesiana; ${ }^{*} \mathrm{C}$. Holmesiana var. tardipes; ${ }^{*} \mathrm{C}$. honesta; ${ }^{*} \mathrm{C}$. horridula; ${ }^{*} \mathrm{C}$. Howeana; ${ }^{*} \mathrm{C}$. hudsonica; ${ }^{*} \mathrm{C}$. hystricina.

${ }^{*}$ Crataegus ideae; ${ }^{*} \mathrm{C}$. illecebrosa; ${ }^{*} \mathrm{C}$. illinoiensis; ${ }^{*} \mathrm{C}$. illuminata; ${ }^{*} \mathrm{C}$. improvisa; ${ }^{*} \mathrm{C}$. inaudita; ${ }^{*} \mathrm{C}$. incaedua; ${ }^{*} \mathrm{C}$. incerta; ${ }^{*} \mathrm{C}$. incisa; ${ }^{*} \mathrm{C}$. inducta; ${ }^{*} \mathrm{C}$. induta; ${ }^{*} \mathrm{C}$. infera; ${ }^{*} \mathrm{C}$. infesta; ${ }^{*} \mathrm{C}$. insignis; ${ }^{*} \mathrm{C}$. insolens; ${ }^{*} \mathrm{C}$. insolita; ${ }^{*} \mathrm{C}$. inspirata; ${ }^{*} \mathrm{C}$. integriloba; C. intricata; ${ }^{*} \mathrm{C}$. inusitula; ${ }^{*} \mathrm{C}$. invisa; ${ }^{*} \mathrm{C}$. irrasa.

${ }^{*}$ Crataegus Jackii; ${ }^{*}$ C. jasperensis; ${ }^{*}$ C. Jenningsii; ${ }^{*}$ C. jejuna; ${ }^{*} \mathrm{C}$. Jonesae; ${ }^{*} \mathrm{C}$. joyana; ${ }^{*} \mathrm{C}$. jozoana.

${ }^{*}$ Crataegus Keepii; ${ }^{*} \mathrm{C}$. Kellermanii; ${ }^{*} \mathrm{C}$. Kennedyi; ${ }^{*} \mathrm{C}$. Kinzerae; ${ }^{*}$ C. kingstonensis; C. Korolkowii.

${ }^{*}$ Crataegus laetans; ${ }^{*} \mathrm{C}$. lanceolata; ${ }^{*} \mathrm{C}$. Laneyi; ${ }^{*} \mathrm{C}$. lanigera; ${ }^{*} \mathrm{C}$. lanuginosa; ${ }^{*} \mathrm{C}$. larga; ${ }^{*} \mathrm{C}$. lasiantha; ${ }^{*} \mathrm{C}$. latifrons; ${ }^{*} \mathrm{C}$. latisepala; ${ }^{*} \mathrm{C}$. laurencensis; ${ }^{*} \mathrm{C}$. laurentiana; ${ }^{*} \mathrm{C}$. lauta; ${ }^{*} \mathrm{C}$. laxiflora; ${ }^{*} \mathrm{C}$. leioclada; ${ }^{*} \mathrm{C}$. leiophylla; ${ }^{*} \mathrm{C}$. lemingtonensis; ${ }^{*} \mathrm{C}$. Lennoniana; ${ }^{*} \mathrm{C}$. lenta; ${ }^{*} \mathrm{C}$. leptophylla; ${ }^{*} \mathrm{C}$. leptopoda; ${ }^{*} \mathrm{C}$. Lettermanii; ${ }^{*} \mathrm{C}$. leucorum; ${ }^{*} \mathrm{C}$. levis; ${ }^{*} \mathrm{C}$. limaria; ${ }^{*} \mathrm{C}$. limosa; ${ }^{*} \mathrm{C}$. littoralis; ${ }^{*} \mathrm{C}$. livoniana; ${ }^{*} \mathrm{C}$. lobulata; ${ }^{*} \mathrm{C}$. locuples; ${ }^{*} \mathrm{C}$. longipedicellata; ${ }^{*} \mathrm{C}$. ludoviciana; ${ }^{*} \mathrm{C}$. luminosa; ${ }^{*} \mathrm{C}$. lutensis; *C. luxuriosa.

${ }^{*}$ Crataegus Macauleyae; ${ }^{*} \mathrm{C}$. macera; ${ }^{*} \mathrm{C}$. Macounii; ${ }^{*} \mathrm{C}$. macrocalyx; ${ }^{*} \mathrm{C}$. macrophylla; ${ }^{*} \mathrm{C}$. macropoda; ${ }^{*} \mathrm{C}$. macrosperma; ${ }^{*} \mathrm{C}$. magnifolia; ${ }^{*} \mathrm{C}$. maineana; ${ }^{*} \mathrm{C}$. maligna; ${ }^{*} \mathrm{C}$. marcida; ${ }^{*} \mathrm{C}$. Margaretta; ${ }^{*} \mathrm{C}$. Margaretta f. xanthocarpa; ${ }^{*} \mathrm{C}$. Maribella; ${ }^{*} \mathrm{C}$. matura; ${ }^{*} \mathrm{C}$. Maximowicziana; ${ }^{*} \mathrm{C}$. media; ${ }^{*} \mathrm{C}$. medioxima; ${ }^{*} \mathrm{C}$. Menandiana; ${ }^{*} \mathrm{C}$. menstrata; ${ }^{*} \mathrm{C}$. merita; ${ }^{*} \mathrm{C}$. metniculosa; ${ }^{*} \mathrm{C}$. micella; ${ }^{*} \mathrm{C}$. michiganensis; ${ }^{*} \mathrm{C}$. micrantha; ${ }^{*} \mathrm{C}$. microsperma; ${ }^{*} \mathrm{C}$. miniata; ${ }^{*} \mathrm{C}$. miranda; ${ }^{*} \mathrm{C}$. missouriensis; ${ }^{*} \mathrm{C}$. mitis; ${ }^{*} \mathrm{C}$. modesta; ${ }^{*} \mathrm{C}$. modica; ${ }^{*} \mathrm{C}$. Mohrii; ${ }^{*} \mathrm{C}$. mollipes; ${ }^{*} \mathrm{C}$. mollis; ${ }^{*} \mathrm{C}$. monstrata; ${ }^{*} \mathrm{C}$. montivaga; ${ }^{*} \mathrm{C}$. munita.

${ }^{*}$ Crataegus napaea; ${ }^{*} \mathrm{C}$. nemoralis; ${ }^{*} \mathrm{C}$. neo-Bushii; ${ }^{*} \mathrm{C}$. neo-fluvialis; ${ }^{*} \mathrm{C}$. neo-londinensis; ${ }^{*} \mathrm{C}$. nescia; ${ }^{*} \mathrm{C}$. nitens; ${ }^{*} \mathrm{C}$. nitida; ${ }^{*} \mathrm{C}$. notabilis; ${ }^{*} \mathrm{C}$. notha; ${ }^{*} \mathrm{C}$. nuda; ${ }^{*} \mathrm{C}$. numerosa; ${ }^{*} \mathrm{C}$. nutans.

${ }^{*}$ Crataegus Oakesiana; ${ }^{*} \mathrm{C}$. oblita; ${ }^{*} \mathrm{C}$. ogdensburgensis; ${ }^{*} \mathrm{C}$. olivacea; ${ }^{*} \mathrm{C}$. opica; ${ }^{*} \mathrm{C}$. opulens; ${ }^{*} \mathrm{C}$. ornata; ${ }^{*} \mathrm{C}$. otiosa; ${ }^{*} \mathrm{C}$. ovata; ${ }^{*} \mathrm{C}$. ovatifolia. 
Crataegus pachyphylla; ${ }^{*} \mathrm{C}$. Paddockeae; ${ }^{*} \mathrm{C}$. padifolia; ${ }^{*} \mathrm{C}$. Paineana; ${ }^{*}$ C. Painteriana; ${ }^{*}$ C. palliata; ${ }^{*}$ C. pallidula; ${ }^{*}$ C. Palmeri; ${ }^{*}$ C. paradoxa; ${ }^{*} \mathrm{C}$. parciflora; ${ }^{*} \mathrm{C}$. Parkae; ${ }^{*} \mathrm{C}$. parviflora; ${ }^{*} \mathrm{C}$. parvula; ${ }^{*} \mathrm{C}$. pastorum; ${ }^{*} \mathrm{C}$. patrum; ${ }^{*} \mathrm{C}$. paucispina; ${ }^{*} \mathrm{C}$. pausiaca; ${ }^{*} \mathrm{C}$. Peckii; ${ }^{*} \mathrm{C}$. pectinata; ${ }^{*} \mathrm{C}$. pedicellata; ${ }^{*} \mathrm{C}$. pellucidula; ${ }^{*} \mathrm{C}$. pennsylvanica; ${ }^{*} \mathrm{C}$. Pennypackeri; ${ }^{*} \mathrm{C}$. pentandra; ${ }^{*} \mathrm{C}$. peoriensis; ${ }^{*} \mathrm{C}$. pequotorum; ${ }^{*} \mathrm{C}$. peramoena; ${ }^{*} \mathrm{C}$. perampla; ${ }^{*} \mathrm{C}$. peregrina; ${ }^{*} \mathrm{C}$. perjucunda; ${ }^{*} \mathrm{C}$. perlaeta; ${ }^{*} \mathrm{C}$. perlevis; ${ }^{*} \mathrm{C}$. permera; ${ }^{*} \mathrm{C}$. perrara; ${ }^{*} \mathrm{C}$. persimilis; C. persistens; C. philadelphica; ${ }^{*} \mathrm{C}$. phleboxia; ${ }^{*} \mathrm{C}$. pilifera; ${ }^{*} \mathrm{C}$. pilosa; ${ }^{*} \mathrm{C}$. pinguis; C. pinnatifida; C. pinnatifida var. major; C. pinnatiloba; ${ }^{*} \mathrm{C}$. Piperi; ${ }^{*} \mathrm{C}$. pisifera; ${ }^{*} \mathrm{C}$. placida; ${ }^{*} \mathrm{C}$. plana; ${ }^{*} \mathrm{C}$. platycarpa; ${ }^{*} \mathrm{C}$. polita; ${ }^{*} \mathrm{C}$. polyclada; ${ }^{*} \mathrm{C}$ populnea; ${ }^{*}$ C. porrecta; ${ }^{*}$ C. Porteri; ${ }^{*} \mathrm{C}$. praeclara; ${ }^{*} \mathrm{C}$. praecogna; ${ }^{*} \mathrm{C}$. praestans; ${ }^{*} \mathrm{C}$. pratensis; ${ }^{*} \mathrm{C}$. Pringlei; ${ }^{*} \mathrm{C}$. Proctoriana; ${ }^{*} \mathrm{C}$. prominens; ${ }^{*} \mathrm{C}$. promissa; ${ }^{*} \mathrm{C}$. prona; ${ }^{*} \mathrm{C}$. propixa; ${ }^{*} \mathrm{C}$. propria; ${ }^{*} \mathrm{C}$. pruinosa; ${ }^{*} \mathrm{C}$. pubifolia; ${ }^{*} \mathrm{C}$. pudens; ${ }^{*} \mathrm{C}$. pulcherima; ${ }^{*} \mathrm{C}$. pulchra; ${ }^{*} \mathrm{C}$. pumila; ${ }^{*} \mathrm{C}$. punctata var. canescens; ${ }^{*} \mathrm{C}$. punctata var. moselemensis; ${ }^{*} \mathrm{C}$. punctata var. mutabilis; ${ }^{*} \mathrm{C}$. pura; ${ }^{*} \mathrm{C}$. pusilla; ${ }^{*} \mathrm{C}$. puta; ${ }^{*} \mathrm{C}$. putata; ${ }^{*} \mathrm{C}$. pygmaea; ${ }^{*} \mathrm{C}$. pyriformis; ${ }^{*}$ Crataegus quercina; ${ }^{*} \mathrm{C}$. quinebaugensis.

${ }^{*}$ Crataegus radiata; ${ }^{*} \mathrm{C}$. radina; ${ }^{*} \mathrm{C}$. radiosa; ${ }^{*} \mathrm{C}$. Randiana; ${ }^{*} \mathrm{C}$. recordabilis; ${ }^{*} \mathrm{C}$. relicta; ${ }^{*} \mathrm{C}$. remota; ${ }^{*} \mathrm{C}$. repentina; ${ }^{*} \mathrm{C}$. repulsans; ${ }^{*} \mathrm{C}$. reses; ${ }^{*} \mathrm{C}$. retrusa; ${ }^{*} \mathrm{C}$. Reverchonii; ${ }^{*} \mathrm{C}$. rhombifolia; ${ }^{*} \mathrm{C}$. rigida; ${ }^{*} \mathrm{C}$. rivalis; ${ }^{*} \mathrm{C}$. Robesoniana; ${ }^{*} \mathrm{C}$. Robinsonii; ${ }^{*} \mathrm{C}$. robusta; ${ }^{*} \mathrm{C}$. rotunda; ${ }^{*} \mathrm{C}$. rotundata; ${ }^{*} \mathrm{C}$. rotundifolia var. aboriginum; ${ }^{*} \mathrm{C}$. rubicunda; ${ }^{*} \mathrm{C}$. rubicundula; ${ }^{*} \mathrm{C}$. rubrifolia; ${ }^{*} \mathrm{C}$. rubrocarnea; ${ }^{*} \mathrm{C}$. rudis; ${ }^{*} \mathrm{C}$. rufipes; ${ }^{*} \mathrm{C}$. ruricola; ${ }^{*} \mathrm{C}$. rustica; ${ }^{*} \mathrm{C}$. rutila.

${ }^{*}$ Crataegus saeva; ${ }^{*} \mathrm{C}$. saligna; ${ }^{*} \mathrm{C}$. sarniensis; ${ }^{*} \mathrm{C}$. saturata; ${ }^{*} \mathrm{C}$. Saundersiana; ${ }^{*}$ C. saxatilis; C. scabra; ${ }^{*}$ C. scabrida; ${ }^{*}$ C. scitula; ${ }^{*}$ C. Searsii; ${ }^{*} \mathrm{C}$. seclusa; ${ }^{*} \mathrm{C}$. secta; ${ }^{*} \mathrm{C}$. sejuncta; ${ }^{*} \mathrm{C}$. sera; ${ }^{*} \mathrm{C}$. serena; ${ }^{*} \mathrm{C}$. sertata; ${ }^{*} \mathrm{C}$. setosa; ${ }^{*} \mathrm{C}$. severa; ${ }^{*} \mathrm{C}$. sextilis; ${ }^{*} \mathrm{C}$. shirleyensis; ${ }^{*} \mathrm{C}$. sicca; ${ }^{*} \mathrm{C}$. sidera; ${ }^{*} \mathrm{C}$. simulans; ${ }^{*} \mathrm{C}$. simulata; ${ }^{*} \mathrm{C}$. sinistra; ${ }^{*} \mathrm{C}$. sitiens; ${ }^{*} \mathrm{C}$. Slavinii; ${ }^{*} \mathrm{C}$. Smithii; ${ }^{*} \mathrm{C}$. sordida; ${ }^{*} \mathrm{C}$. spatiosa; ${ }^{*} \mathrm{C}$. speciosa; ${ }^{*} \mathrm{C}$. spinulosa; ${ }^{*} \mathrm{C}$. stenophylla; ${ }^{*} \mathrm{C}$. Stonei; ${ }^{*} \mathrm{C}$. stolonifera; ${ }^{*} \mathrm{C}$. Streeterae; ${ }^{*} \mathrm{C}$. strigosa; ${ }^{*} \mathrm{C}$. strongylophylla; ${ }^{*} \mathrm{C}$. structilis; ${ }^{*} \mathrm{C}$. suavis; ${ }^{*} \mathrm{C}$. submollis; ${ }^{*} \mathrm{C}$. suborbiculata; ${ }^{*} \mathrm{C}$. succincta; ${ }^{*} \mathrm{C}$. swanensis.

${ }^{*}$ Crataegus taetrica; ${ }^{*} \mathrm{C}$. tantula; ${ }^{*} \mathrm{C}$. tarda; ${ }^{*} \mathrm{C}$. tardipes; ${ }^{*} \mathrm{C}$. Tatnalliana; ${ }^{*} \mathrm{C}$. tenax; ${ }^{*} \mathrm{C}$. tenella; ${ }^{*} \mathrm{C}$. tenera; ${ }^{*} \mathrm{C}$. tenuiloba; ${ }^{*} \mathrm{C}$. tenuisepala; ${ }^{*} \mathrm{C}$. texana; ${ }^{*} \mathrm{C}$. Thayeri; ${ }^{*} \mathrm{C}$. tomentosa; ${ }^{*} \mathrm{C}$. torta; ${ }^{*} \mathrm{C}$. tortuosa; ${ }^{*} \mathrm{C}$. trachyphylla; ${ }^{*} \mathrm{C}$. trahax; ${ }^{*} \mathrm{C}$. trianthophora; ${ }^{*} \mathrm{C}$. tribulosa; ${ }^{*} \mathrm{C}$. tripartita; ${ }^{*}$ C. triumphalis; ${ }^{*} \mathrm{C}$. truculenta;

${ }^{*}$ Crataegus umbratilis; ${ }^{*} \mathrm{C}$. umbrosa; ${ }^{*} \mathrm{C}$. uniqua; ${ }^{*} \mathrm{C}$. uplandia; ${ }^{*} \mathrm{C}$. urbana; ${ }^{*} \mathrm{C}$. uticaensis.

${ }^{*}$ Crataegus vaga; ${ }^{*} \mathrm{C}$. vallicola; ${ }^{*} \mathrm{C}$. varians; ${ }^{*} \mathrm{C}$. vegeta; ${ }^{*} \mathrm{C}$. velutina; ${ }^{*} \mathrm{C}$. venulosa; ${ }^{*} \mathrm{C}$. venusta; ${ }^{*} \mathrm{C}$. venustula; ${ }^{*} \mathrm{C}$. verecunda; ${ }^{*} \mathrm{C}$. verruculosa; ${ }^{*} \mathrm{C}$. vicina; ${ }^{*} \mathrm{C}$. vicinalis; ${ }^{*} \mathrm{C}$. villicarpa; ${ }^{*} \mathrm{C}$. villiflora; ${ }^{*} \mathrm{C}$. villipes; ${ }^{*} \mathrm{C}$. virella; ${ }^{*} \mathrm{C}$. viridimontana; ${ }^{*} \mathrm{C}$. viridis; ${ }^{*} \mathrm{C}$. vittata; ${ }^{*} \mathrm{C}$. vivida. 
${ }^{*}$ Crataegus Websteri; ${ }^{*} \mathrm{C}$. Wheeleri; ${ }^{*} \mathrm{C}$. Williamsii; ${ }^{*} \mathrm{C}$. wilmorensis; ${ }^{*} \mathrm{C}$. Wilsonii.

${ }^{*}$ Crataegus xanthophylla.

Cryptomeria japonica var. globosa nana.

*Cunninghamia Konishii.

Cytisus albus var. schipkaensis; $\times$ C. Beanii; C. elongatus; C. glabrescens; C. nigricans; C. nigrescens var. Carlierii; C. purgans; C. scoparius var. Andreanus f. compactus.

Dalbergia hupeana.

Daphne altaica; D. altaica var. Sophia; D. caucasica; D. genkwa (Chinese form); *D. Giraldii; D. retusa; *D. tangutica.

Daphniphyllum humile.

Davidia involucrata; D. involucrata var. Vilmoriniana.

Debregeasia longifolia.

Decaisnea Fargesii.

*Decumaria sinensis.

*Desmodium serriferum; *D. spicatum; D. tiliaefolium.

*Deutzia coreana; D. discolor; ${ }^{*} \mathrm{D}$. glabrata; D. glomeruliflora; ${ }^{*} \mathrm{D}$. grandiflora; ${ }^{*} \mathrm{D}$. hypoleuca; D. longifolia; ${ }^{*} \mathrm{D}$. longifolia var. elegans; D. mollis; D. parviflora; D. parviflora var. ovatifolia; *D. pulchra; D. purpurascens; *D. Schneideriana var. laxiflora; D. setchuenensis; D. setchuenensis var. corymbiflora; D. Vilmorinae; D. Wilsonii.

*Diervilla florida var. venusta; D. japonica; D. japonica var. sinica; *D. Maximowiczii; D. Middendorfiana.

Dipelta floribunda; D. ventricosa;

Dipteronia sinensis.

*Disanthus cercidifolius.

*Echinopanax elatus.

Ehretia acuminata; E. Dicksonii.

Elsholtzia polystachya; *E. Stauntonii.

Emmenopterys Henryi.

*Enkianthus campanulatus var. albiflora; E. campanulatus var. Palibiniana; E. cernuus var. rubens; E. deflexus; E. quinqueflorus var. serrulatus; ${ }^{*} \mathrm{E}$. subsessilis.

*Epigaea asiatica.

Eucommia ulmoides.

Euptelea Franchetii; *E. pleiosperma; E. polyandra.

Eurotia lanata.

Euscaphis japonica.

*Evodia Daniellii; E. glauca; E. Henryi; E. hupehensis; *E. officinalis; ${ }^{*} \mathrm{E}$. velutina.

Evonymus acanthocarpa; *E. alata var. aperta; *E. aquifolium; E. Bungeana; E. Bungeana var. semipersistens; E. cornuta; ${ }^{*}$ E. elegantissima; E. lanceifolia; E. Maackii; E. macroptera; E. nana; E. oxyphylla; E. planipes; ${ }^{*} \mathrm{E}$. porphyrea; ${ }^{*} \mathrm{E}$. radicans var. microphylla; ${ }^{*} \mathrm{E}$. radicans 
var. acuta; ${ }^{*}$ E. radicans var. vegeta; E. sanguinea; *E. Sargentiana; E. subsessilis.

Exochorda Giraldii; *E. Giraldii var. Wilsonii; $\times$ E. macrantha; E. serratifolia.

${ }^{*}$ Fagus Engleriana; ${ }^{*} \mathrm{~F}$. japonica; ${ }^{*} \mathrm{~F}$. longipetiolata; ${ }^{*} \mathrm{~F}$. lucida; F. orientalis; ${ }^{*}$ F. Sieboldii; F. sylvatica var. dawyckii.

Foresteeria neomexicana; ${ }^{*} \mathbf{F}$. pubescens.

*Forsythia ovata; *F. suspensa f. pubescens; F. suspensa var. Fortunei f. atrocaulis; $\times F$. intermedia var. spectabilis.

*Fortunearia sinensis.

*Fraxinus americana var. crassifolia; F. anomala; F. Bungeana; F. chinensis; F. chinensis var. rhynchophylla; F. dumosa; F. elonza; F. glabra; F. holotricha; F. Hookeri; ${ }^{*}$ F. Lowellii; F. Mariesii; F. obliqua; F. obovata; F. oxycarpa; F. parvifolia; F. parvifolia var. monophylla; F. parvifolia var. nana; F. Paxiana; F. platypoda; F. potamophila; *F. profunda; F. pubinervis; F. Regelii; F. retusa var. Henryi; F. rotundifolia; F. rotundifolia var. pendula; F. Spaethiana; F. tamariscifolia; ${ }^{*}$ F. texensis; F. velutina var. coriacea; F. velutina var. glabra; F. Veltheimii; F. Willdenowiana; F. xanthoxyloides.

${ }^{*}$ Gaultheria adenothrix; ${ }^{*} \mathrm{G}$. cuneata; ${ }^{*} \mathrm{G}$. moupinensis; G. Veitchiana.

Genista radiata.

*Gleditsia horrida; G. macracantha; G. sinensis; *×G. texana.

Glycyrrhiza suffrutescens; G. uralensis.

Gordonia axillaris.

Grewia parviflora; *G. parviflora var. glabrescens.

Gymnocladus chinensis.

*Hamamelis incarnata; H. japonica; H. japonica var. arborea; H. mollis; ${ }^{*} \mathrm{H}$. vernalis; ${ }^{*} \mathrm{H}$. virginiana var. rubescens.

Hedysarum multijugum.

${ }^{*}$ Helwingia chinensis; H. japonica.

Hemiptelea Davidii.

${ }^{*}$ Holboellia coriacea; ${ }^{*} \mathrm{H}$. grandiflora.

Hydrangea anomala; $\mathbf{H}$. arborescens var. urticifolia; $\mathbf{H}$. Bretschneideri; ${ }^{*} H$. Bretschneideri var. setchuenensis; ${ }^{*} H$. Davidii; H. hirta; H. involucrata; H. longipes; $H$. opuloides var. cyanoclada; $H$. opuloides var. serrata; H. Rosthornii; ${ }^{*}$ H. Sargentiana; H. strigosa; H. strigosa var. macrophylla; *H. villosa; H. xanthoneura; H. xanthoneura var. glabrescens; ${ }^{*}$ H. xanthoneura var. Wilsonii.

${ }^{*}$ Hypericum aureum; ${ }^{*}$ H. Buckleyi; ${ }^{*}$ H. galioides; H. patulum var. Henryi.

*Idesia polycarpa var. vestita.

Ilex aquifolium var. chinensis; *I. ciliospinosa; I. corallina; I. crenata var. nummularia; I. decidua; I. Fargesii; I. fragilis; *I. Franchetiana; *I. geniculata; I. integra; I. leucoclada; I. longipes; *I. macrocarpa; *I. monticola; *I. opaca var. xanthocarpa; ${ }^{*}$ I. pedunculosa; I. pedunculosa 
f. continentalis; I. Pernyi; I. Pernyi var. Veitchii; I. purpurea var. Oldhamii; *I. rugosa; I. serrata; *I. serrata var. argutidens; *I. Sugerokii; *I. szechwanensis; *I. verticillata var. chrysocarpa; I. yunnanensis.

*Indigofera amblyantha; I. decora; I. hebepetala; I. Kirilowii; *I. Potaninii.

\section{Itea ilicifolia.}

Jasminum Beesianum; J. lanceolarium; J. urophyllum.

Juglans boliviensis; J. cathayensis; *J. formosana; $\times J$. intermedia; J. regia var. sinensis; J. rupestris; J. Sieboldiana var. cordiformis.

*Juniperus chinensis var. Sargentii; *J. communis var. Jackii; *J. communis var. nipponica; *J. conferta; J. formosana; ${ }^{*} J$. Pinchotii; J. rigida; *J. scopulorum; J. squamata var. Fargesii; *J. squamata var. Wilsonii; *J. taxifolia.

Kalmia caroliniana; K. cuneata; *K. hirsuta; *K. latifolia var. obtusata; *K. latifolia f. polypetala.

Koelreuteria apiculata.

Kolkwitzia amabilis.

Laburnum caramanicum.

Larix dahurica; L. dahurica var. japonica; ${ }^{*} \mathrm{~L}$. dahurica var. Principis Rupprechtii; $\times$ L. eurolepis; ${ }^{*} \mathrm{~L}$. Kaempferi var. minor; *L. Lyallii; ${ }^{*} \mathrm{~L}$. Mastersiana; ${ }^{*}$ L. occidentalis; $\times$ L. pendula; L. Potaninii; L. sibirica.

Leptodermis oblonga.

${ }^{*}$ Lespedeza Buergeri; *L. Buergeri var. praecox; L. cyrtobotrya.

${ }^{*}$ Leucothoe Grayana; *L. Keiskei; *L. recurva.

*Ligustrum acuminatum; L. acuminatum var. macrocarpum; Ligustrum acutissimum; L. Delavayanum; L. Henryi; L. Quihoui.

Liquidambar formosana; ${ }^{*} \mathrm{~L}$. formosana var. monticola.

Liriodendron chinense; L. Tulipifera var. fastigiatum.

Lithocarpus cleistocarpa; L. Henryi.

Lonicera alseuosmoides; L. Altmannii L. Altmannii var. hirtipes; L. Altmannii var. pilosiuscula; L. angustifolia; L. arborea var. persica; L. arizonica; L. bella; L. bracteolaris; L. chaetocarpa; L. Chamissoi; *L. demissa; L. deflexicalyx; L. discolor; ${ }^{*}$ L. Ferdinandii; L. Ferdinandii var. leycesterioides; L. Giraldii; L. gynochlamydea; L. Henryi; *L. heteroloba; L. hispida; L. involucrata var. flavescens; L. involucrata var. humilis; L. involucrata var. serotina; L. Koehneana; *L. Korolkovii; L. Korolkovii var. floribunda; L. lanceolata; L. Maackii; L. Maackii var. podocarpa; *I. Maackii var. podocarpa f. erubescens; L. Maximowiczii; ${ }^{*}$ L. Maximowiczii var. sachalinensis; L. microphylla; $L$. minutiflora; $L$. Morrowii; ${ }^{*} \mathrm{~L}$. moupinensis; ${ }^{*} \times \mathrm{L}$. muendeniensis; ${ }^{*} \times \mathrm{L}$. muscaviensis; L. myrtilloides; L. Myrtillus; L. nervosa; ${ }^{*}$ L. nitida; ${ }^{*} \mathrm{~L}$. notha; L. pileata; ${ }^{*} \mathrm{~L}$. praeflorens; L. prostrata; L. purpurascens; L. pyrenaica; L. quinquelocularis; L. rupicola; L. Ruprechtiana var. calvescens; ${ }^{*} \mathrm{~L}$. Ruprechtiana var. xanthocarpa; L. saccata; ${ }^{*}$ L. Schneideriana; L. Semenovii; L. similis var. Delavayi; L. spinosa var. Alberti; L. Standishii 
var. lancifolia; ${ }^{*} \mathrm{~L}$. strophiophora; ${ }^{*} \mathrm{~L}$. subaequalis; ${ }^{*} \mathrm{~L}$. subdentata; L. syringantha; L. syringantha var. Wolfii; ${ }^{*} \mathrm{~L}$. szechuanica; L. tangutica; ${ }^{*} \mathrm{~L}$. tatsienensis; ${ }^{*} \mathrm{~L}$. tenuipes; L. thibetica; L. tomentella; L. tragophylla; L. trichosantha; L. utahensis; L. Vilmorinii; L. Webbiana; L. xerocalyx; L. xylosteoides.

${ }^{*}$ Lysionotus pauciflorus.

${ }^{*}$ Maackia amurensis var. Buergeri; ${ }^{*} \mathrm{M}$. chinensis; ${ }^{*} \mathrm{M}$. Fauriei; M. Tashiroi.

Maddenia hypoleuca; *M. Wilsonii.

*Magnolia Dawsoniana; M. denudata var. purpurascens; *M. kobus var. borealis; ${ }^{*}$ M. Nicholsoniana; M. officinalis; ${ }^{*}$ M. parviflora (Korean form); *M. salicifolia; *M. Sargentiana; *M. Sargentiana var. robusta; M. Wilsonii.

${ }^{*}$ Malus baccata f. Jackii; M. baccata var. mandshurica; *M. bracteata; *M. coronaria var. Charlottae; *M. coronaria var. elongata; $\times M$. Eleyi; M. florentina; M. floribunda var. brevipes; *M. formosana; ${ }^{*} \mathbf{M}$. glabrata; ${ }^{*} \mathbf{M}$. ioensis var. Bushii; ${ }^{*} \mathbf{M}$. ioensis var. Palmeri; ${ }^{*} \mathbf{M}$. kansuensis; ${ }^{*}$ M. kansuensis var. calva; ${ }^{*}$ M. Komarovii; ${ }^{*}$ M. lancifolia; $\times \mathbf{M}$. magdeburgensis; M. micromalus; M. Prattii; M. prunifolia var. rinki; *M. prunifolia var. rinki (cult. Korea); M. pumila var. Niedzwitzkyana; M. robusta var. persicifolia; *M. Sargentii; M. Sieboldii; *M. Sieboldii var. arborescens; ${ }^{*}$ M. Sieboldii var. calocarpa; M. sikkimensis; ${ }^{*}$ M. spontanea; $\times \mathbf{M}$. sublobata; M. theifera; M. theifera $\mathrm{f}$. rosea; ${ }^{*} \mathbf{M}$. toringoides; ${ }^{*} \mathbf{M}$. transitoria; M. trilobata; ${ }^{*}$ M. Tschonoskii; M. yunnanensis; M. zumi.

*Meliosma Beaniana; M. cuneifolia; M. myriantha; *M. pendens; *M. tenuis; M. Veitchiorum.

${ }^{*}$ Menziesia ciliicalyx; ${ }^{*}$ M. multiflora; M. pentandra; *M. purpurea.

Morus acidosa; ${ }^{*}$ M. cathayana; M. mongolica; ${ }^{*}$ M. notabilis.

${ }^{*}$ Neillia longiracemosa; N. sinensis; ${ }^{*}$. thibetica.

Nothopanax Davidii.

Orixa japonica.

Osmanthus armatus; ${ }^{*} O$. serrulatus.

*Osteomeles Schwerinae var. microphylla.

Ostrya carpinifolia; ${ }^{*} O$. japonica; ${ }^{*} O$. Knowltonii.

Ostryopsis Davidiana.

Pachystima myrsinites.

Paederia tomentosa.

Paeonia Delavayi; *P. Delavayi var. angustiloba; *P. suffruticosa (wild form).

Parrotiopsis Jacquemontiana.

Parthenocissus Henryana; P. himalayana; *P. himalayana var. rubrifolia; *P. laetevirens; P. Thomsonii.

*Paulownia Mikado; *P. tomentosa var. lanata.

*Pentactina rupicola.

*Pentapanax Henryi. 
*Periploca sepium.

Petrophytum caespitosum.

Phellodendron amurense; P. chinense; P. Lavalleii; *P. sachalinense.

*Philadelphus argyrocalyx; P. Delavayanus; P. incanus; P. Magdalenae; *P. microphyllus; P. pekinensis; P. pekinensis var. brachybotrys; P. purpurascens; *P. sericanthus var. Rehderianus; *P. serpyllifolius; P. Schrenkii var. Jackii; P. subcanus; P. tenuifolius.

Photinia Beauverdiana var. notabilis; *P. Davidsoniae; *P. subumbellata; P. villosa var. laevis; $P$. villosa var. sinica.

Phyllodoce glanduliflora; *P. nipponica.

Picea Abies var. aclada; P. Abies var. conica elegans; P. Abies var. decumbens; P. Abies var. dumosa; P. Abies var. elegans; P. Abies var. nidiformis; P. Abies var. pachyphylla; P. Abies var. prostrata; P. Abies var. pygmaea globosa; P. Abies var. pyramidalis compacta; P. Abies var. pyriformis; P. Abies, var. repens; *P. ascendens; *P. asperata; *P. asperata var. notabilis; ${ }^{*} \mathrm{P}$. asperata var. ponderosa; ${ }^{*} \mathrm{P}$. aurantiaca; ${ }^{*} \mathrm{P}$. Balfouriana; ${ }^{*}$ P. Breweriana; P. complanata; ${ }^{*}$. Engelmannii; ${ }^{*} \mathrm{P}$. glauca var. albertiana $f$. conica; P. glauca var. compacta globosa; P. glauca var. nana; P. Glehnii; *P. heterolepis; *P. koraiensis; *P. Koyamai; ${ }^{*}$ P. Meyeri; ${ }^{*}$ P. montigena; ${ }^{* P}$. morrisonicola; P. omorika; ${ }^{*}$. pungens var. compacta; ${ }^{*} \mathrm{P}$. purpurea; ${ }^{*} \mathrm{P}$. retroflexa; $\mathrm{P}$. rubra var. virgata; *P. Sargentiana; P. Watsoniana; *P. Wilsonii.

Picrasma quassioides.

*Pieris nana; P. ovalifolia var. lanceolata; *P. taiwanensis.

*Pilostegia viburnoides.

Pinus Armandi; P. echinata; P. leucodermis; P. peuke; P. pumila; P. sinensis; ${ }^{*} \mathbf{P}$. sinensis var. densata; ${ }^{*} \mathbf{P}$. sinensis var. yunnanensis; $\mathbf{P}$. Strobus var. fastigiata; *P. Strobus var. prostrata.

Piptanthus concolor.

*Pittosporum daphniphylloides; P. glabratum; *P. heterophyllum; P. truncatum.

Platanus Wrightii.

Platycarya strobilacea.

Poliothyrsis sinensis.

Polygonum multiflorum.

*Populus adenopoda; * $\times$ P. Andrewsii; $\times$ P. generosa; *P. koreana; P. lasiocarpa; *P. Palmeri; P. Petrowskiana; P. Sieboldii; *P. szechuanica; P. tomentosa; *P. tremula var. Davidiana; *P. tremula var. Davidiana f. tomentella; *P. Wilsonii.

${ }^{*}$ Potentilla fruticosa var. albicans, ${ }^{*} \mathrm{P}$. fruticosa var. parvifolia; P. fruticosa var. Purdomii; P. fruticosa var. tenuifolia; P. fruticosa var. Veitchii; P. Vilmoriniana.

Prinsepia sinensis; *P. uniflora.

${ }^{*}$ Prunus alabamensis; ${ }^{*} \mathrm{P}$. alleghaniensis; ${ }^{*} \mathrm{P}$. alleghaniensis var. Davisii; $\times$ P. amygdalo-persica; P. apetala; P. armeniaca var. mikado; 
${ }^{*}$ P. australis; P. baldschuanica; *P. bicolor; *P. brachypoda var. pseudossiori; P. Buergeriana; P. campanulata; P. canescens P. cerasifera var. divaricata; P. concinna; ${ }^{*}$ P. Conradinae; ${ }^{*}$ P. Cuthbertii; ${ }^{*}$ P. cyclamina; P. dasycarpa; P. dasycarpa var. salicifolia; P. Davidiana; *P. dehiscens; *P. Dielsiana; *P. discadenia; P. emarginata; *P. glyptocarya; ${ }^{*} \mathrm{P}$. gracilis; ${ }^{*} \mathrm{P}$. Gravesii; ${ }^{*} \mathrm{P}$. hortulana var. pubens; $\mathrm{P}$. humilis; $\mathbf{P}$. incana; P. incisa; *P. incisa f. serrata; P. Jacquemontii; *P. japonica var. Nakaii; P. Lannesiana f. albida; P. Lannesiana f. benitoranowo; P. Lannesiana f. botanzakura; P. Lannesiana f. chosiuhizakura; P. Lannesiana f. fudanzakura; P. Lannesiana f. fukurokuju; P. Lannesiana f. gijozakura; P. Lannesiana f. gozanomanioi; P. Lannesiana f. hatazakura; P. Lannesiana $f$. higurashi; $P$. Lannesiana $f$. horaisan; P. Lannesiana f. jonioi; $P$. Lannesiana f. kokesimidsu; P. Lannesiana f. mazakura; P. Lannesiana f. mikurumakaisi; P. Lannesiana f. miyako; P. Lannesiana f. ohsibayama; P. Lannesiana f. sobanzakura; P. Lannesiana f. sumizome; P. Lannesiana f. surugadainioi; P. Lannesiana f. takinioi; P. Lannesiana f. temari; P. Lannesiana f. yedozakura; P. Laucheana; P. Laurocerasus var. schipkaensis; *P. lobulata; P. Maackii; *P. malifolia; *P. Maximowiczii; ${ }^{*} \mathrm{P}$. mexicana; *P. mexicana var. fultonensis; P. microcarpa; ${ }^{*} \mathrm{P}$. micromeloides; *P. mira; P. emarginata var. mollis; P. nana; P. nana var. caucasica; P. nana var. transcaucasica; P. nipponica; P. nipponica var. kurilensis; *P. orthosepala; P. Padus var. Albertii; P. Padus var. commutata; P. Padus var. heterophylla; P. Padus var. parviflora; P. Padus var. sibirica; ${ }^{*}$ P . perulata; P. Petunikovii; ${ }^{*}$ P. pilosiuscula var. barbata; ${ }^{*} \mathrm{P}$. pilosiuscula var. media; ${ }^{*} \mathrm{P}$. pleiocerasus; ${ }^{*} \mathrm{P}$. pleuroptera; ${ }^{*} \mathrm{P}$. plurinervis; *P. polytricha; P. prostrata; *P. pubigera var. obovata; *P. pubigera var. Prattii; *P. Reverchonii; P. rufomicans; P. salicina (wild form); *P. serrula var. tibetica; P. serrulata var. pubescens; P. serrulata var. pubescens $f$. meigetsu; P. serrulata var. pubescens $f$. taizanfukun; $P$. serrulata $f$. rosea; ${ }^{*} P$. serrulata var. sachalinensis; $P$. serrulata var. sachalinensis $\mathbf{f}$. horinji; $P$. serrulata var. sachalinensis $f$. kokonaye; $P$. serrulata var. sachalinensis $f$. ohnanden; $P$. serrulata var. sachalinensis $f$. sekiyama; P. serrulata var. sachalinensis f. shogetsu; P. serrulata var. sachalinensis f. udzuzakura; P. serrulata var. spontanea; P. serrulata var. spontanea f. kosioyama; P. serrulata var. spontanea f. praecox; P. sibirica; P. Sieboldii f. yokihi; P. Ssiori; ${ }^{*}$ P. stellipila; ${ }^{*}$ P. subhirtella; ${ }^{*}$ P. subhirtella var. ascendens; ${ }^{*}$ P. tatsienensis var. stenadenia; P. tomentosa; P. tomentosa var. endotricha; $P$. triloba var. normalis; ${ }^{*} \mathrm{P}$. variabilis; ${ }^{*} P$. venosa; ${ }^{*} P$. virens; $P$. virginiana var. demissa $\mathrm{f}$. pachyrrachis; $P$. virginiana var. leucocarpa; *P. Watsonii; P. Wilsonii var. leiobotrys; P. yedoensis.

Pseudotsuga japonica.

*Ptelea Baldwinii; *P. isophylla; P. polyadenia.

Pterocarya hupehensis; P. Paliurus; P. rhoifolia.

Pteroceltis Tatarinowii. 
Pterostyrax corymbosum; P. hispidum.

*Pyracantha Gibbsii; P. Koidzumii.

Pyrus amygdaliformis; P. amygdaliformis var. oblongifolia; P. Balansae; P. betulaefolia; P. Bretschneideri; ${ }^{*}$ P. Calleryana; *P. Calleryana var. dimorphophylla; *P. Calleryana var. Fauriei; *P. Calleryana var. tomentella; P. communis var. cordata; P. communis var. cotinifolia; P. communis var. fascicularis; P. communis var. pyraster; *P. Kawakamii; P. Korshinskyi; P. Michauxii; P. pashia; P. persica; P. phaeocarpa; P. phaeocarpa var. globosa; P. Pyrainus; P. serotina; *P. serrulata; P. ussuriensis; ${ }^{*} \mathrm{P}$. ussuriensis var. hondoensis; $\mathrm{P}$. ussuriensis var. ovoidea.

${ }^{*}$ Quercus aliena; ${ }^{*} \mathbf{Q}$. aliena var. acuteserrata; ${ }^{*} \mathbf{Q}$. aliena var. acuteserrata f. calvescens; $\mathbf{Q}$. aquifolioides var. rufescens; ${ }^{*} \mathbf{Q}$. arkansana; $\mathbf{Q}$. Baronii; $\times$ Quercus Bebbiana; ${ }^{*} \mathbf{Q}$. ellipsoidalis; ${ }^{*} \mathbf{Q}$. Engleriana; Q. Gambelii; Q. Gilliana; Q. glandulifera; ${ }^{*} \mathbf{Q}$. glauca var. gracilis; $\times \mathbf{Q}$. guadalupensis; Q. Gunnisonii; ${ }^{*}$ Q. Havardii; ${ }^{*} \times$ Q. Jackii; *Q. Laceyi; ${ }^{*} \times \mathbf{Q}$. Leana; *Q. leptophylla; *Q. liaotungensis; $Q$. libani var. angustifolia; Q. lyrata; Q. macedonica; Q. macranthera; ${ }^{*} \mathrm{Q}$. mongolica; ${ }^{*} \mathrm{Q}$. mongolica var. grosseserrata; ${ }^{*} \mathrm{Q}$. Muehlenbergii var. Brayi; ${ }^{*} \mathrm{Q}$. nigra var. tridentifera f. microcarya; ${ }^{*} \mathrm{Q}$. nitescens; $\mathrm{Q}$. oxyodon; ${ }^{*} \mathrm{Q}$. pachyloma; ${ }^{*} \times$ Q. Rehderi; Q. pontica; ${ }^{*} \times \mathbf{Q}$. Robbinsii; Q. robur var. pectinata; ${ }^{*} \mathrm{Q}$. rubra var. pagodaefolia; ${ }^{*} \times \mathbf{Q}$. runcinata; $\mathrm{Q}$. semicarpifolia; $\mathrm{Q}$. serrata; Q. serratifolia; Q. sessiliflora var. insecata; Q. sessiliflora var. Loucttei; ${ }^{*}$ Q. Shumardii; ${ }^{*}$ Q. Shumardii var. Schneckii; ${ }^{*} Q$. stellata var. Boyntonii; $\times \mathbf{Q}$. subfalcata var. microcarpa; Q. toza; *Q. undulata; *Q. utahensis; ${ }^{*} \mathbf{Q}$. utahensis var. submollis; $Q$. variabilis; ${ }^{*} Q$. velutina var. missouriensis.

*Reevesia pubescens.

Rhamnella franguloides.

Rhamnus costata; R. crenata; ${ }^{*}$. dumetorum; ${ }^{*}$ R. dumetorum var. crenoserrata; R. fallax; ${ }^{*} \mathbf{R}$. heterophylla; ${ }^{*} \mathbf{R}$. hupehensis; ${ }^{*} \mathbf{R}$. koraiensis; ${ }^{*}$ R. leptacantha; R. leptophylla; *R. Leveilleana; R. nipponica; ${ }^{*}$ R. paniculiflora; R. parviflora; *R. Rosthornii; *R. Sargentiana; ${ }^{*}$ R. Schneideri; R. utilis; R. virgata.

${ }^{*}$ Rhododendron alabamense; ${ }^{*}$ R. Albrechtii; R. ambiguum; ${ }^{*} \mathbf{R}$. Amesiae; R. argyrophyllum; R. argyrophyllum var. cupulare; R. Augustinii; *R. austrinum; *R. bracteatum; R. calophytum; *R. Chapmanii; R. concinnum; ${ }^{*}$ R. Davidsonianum; R. decorum; R. discolor; ${ }^{*}$ R. Edgarianum; R. Faberi; R. Fargesii; R. flavidum; *R. floribundum; R. Fortunei var. Houlstonii; ${ }^{*} \mathrm{R}$. galacteum; ${ }^{*} \mathrm{R}$. Hanceanum; *R. Hunnewellianum; R. hypoglaucum; R. indicum; *R. insigne; R. intricatum; R. japonicum; ${ }^{*}$ R. japonicum f. aureum; ${ }^{*}$ R. Keiskei; R. linearifolium var. macrosepalum; R. longesquamatum; ${ }^{*} \mathbf{R}$. longistylum; $\mathbf{R}$. lutescens; R. maculiferum; R. Mariesii; ${ }^{*}$ R. Metternichii; R. micranthum; ${ }^{*}$ R. Morii; *R. moupinense; R. mucronulatum; R. mucronatum f. sekidera; ${ }^{*} \mathbf{R}$. mucronulatum var. ciliatum; ${ }^{*} \mathbf{R}$. nipponicum; ${ }^{*} \mathbf{R}$. obtusum var. 
japonicum; ${ }^{*}$ R. obtusum var. Kaempferi; ${ }^{*}$ R. obtusum var. Kaempferi f. multicolor; R. Oldhami; R. orbiculare; R. oreodoxa; R. pachytrichum; *R. phoenicium var. tebotan; R. pittosporaefolium; R. polylepis; *R. prunifolium; R. Przewalskii; ${ }^{*}$ R. pseudochrysanthum; R. reticulatum; *R. rubropilosum; *R. Sargentianum; R. scabrum; R. Schlippenbachii; ${ }^{*} \mathbf{R}$. Searsiae; ${ }^{*} \mathbf{R}$. semibarbatum; ${ }^{*} \mathbf{R}$. serrulatum; R. Smirnovii; R. Souliei; ${ }^{*}$ R. stamineum; ${ }^{*} \mathbf{R}$. strigillosum; R. sutchuenense; R. taliense; ${ }^{*} R$. Thayerianum; ${ }^{*}$. tosaense; T. Tschonoskii; R. Ungerni; ${ }^{*} R$. violaceum; R. Wasonii; R. Watsonii; ${ }^{*}$ R. Websterianum; ${ }^{*}$ R. Weldianum; ${ }^{*} R$. Weyrichii; ${ }^{*}$ R. Williamsianum; R. yanthinum; ${ }^{*}$. yedoense var. poukhanense.

\section{KURUME AZALEAS}

Rhododendron obtusum var. japonicum $f$.

"Agemaki"
"Aioi"
"Asagasumi",
"Aya Kammuri"
"Azuma Kagami"
"Benifude"
"Bijinsui"
"Fudesute Yama"
"Gosho Zakura"
"Hachika Tsugi"
"Hana Asobi"
"Hinode No Taka"
"Hoō"
"Ima Shōjō"
"Irohayama"
"Kasane Kagaribi"
"Kasumi Gaseki"
"Katsura No Hana"
"Kimigayo"
"Kirin"
"Kiritsubo"
"Kumo No Uye"
"Kurai No Himo"
"Kureno Yuki"
"Nani Wagata"

"Oinō Mezame"

"Omoine"

"Osaraku"

"Osaraku Seedling"

"Otome"

"Rashō Mon"

"Sakura Tsukasa"

"Saotome"

"Seikai"

"Shin Seikai"

"Shin Utena"

"Shintoki No Hagasane"

"Suetsumu"

"Suga No Ito"

"Suiyōhi"

"Takasago"

"Tama No Utena"

"Tamafuyo"

"Tancho"

"Tsuta Momiji"

"Ukamuse"

"Waka Kayede"

"Yayehiryu"

"Yorozuyo"

Rhus Potaninii; R. punjabensis var. sinica; *R. sylvestris; ${ }^{*} \mathbf{R}$. trichocarpa; ${ }^{*} \mathbf{R}$. trilobata; $\mathbf{R}$. verniciflua.

Ribes aciculare; $\mathbf{R}$. alpestre; ${ }^{*} \mathbf{R}$. alpestre var. giganteum; $\mathbf{R}$. alpinum var. pumilum; *R. ambiguum; R. burejense; ${ }^{*}$ R. cognatum; R. dikuscha var. appendiculatum; R. fasciculatum; R. fasciculatum var. chinense; 
$\times$ R. fuscescens; R. Giraldii; R. glaciale; *R. glaciale var. angustisepala; R. grossularioides; ${ }^{*} \mathbf{R}$. Henryi; R. heterotrichum; ${ }^{*} \mathbf{R}$. himalayense var. atropurpureum; $\mathbf{R}$. himalayense var. urceolatum; ${ }^{*} \mathbf{R}$. japonicum; ${ }^{*} \mathbf{R}$. laurifolium; R. laxiflorum; R. leptanthum; R. longeracemosum; ${ }^{*} \mathbf{R}$. longeracemosum var. Wilsonii; R. luridum; *R. magellanicum; R. mandshuricum var. subglabrum; R. Maximowiczii; ${ }^{*} \mathbf{R}$. mescalerium; $\mathbf{R}$. Meyeri var. turkestanicum; R. montigenum; R. moupinense; *R. moupinense var. laxiflorum; $\mathbf{R}$. orientale; ${ }^{*} \mathbf{R}$. parvulum; ${ }^{*} \mathbf{R}$. petiolare; $\mathbf{R}$. petraeum; R. petraeum var. altissimum; R. petraeum var. Biebersteinii; ${ }^{*} \mathbf{R}$. pinetorum; *R. Pringlei; R. procumbens; R. saxatile; R. Spaethianum; R. stenocarpum; $\times \mathbf{R}$. succirubrum; R. tenue; Ribes tricuspe; R. ussuriense; $\mathbf{R}$. Vilmorinii; ${ }^{*} \mathbf{R}$. viscosissimum.

Robinia Hartwigii; *R. neomexicana.

*Rosa adenosepala; R. amblyotis; ${ }^{*} \mathbf{R}$. Bakeri; R. banksiopsis; *R. bella; *R. bella var. pallens; R. caudata; R. corymbulosa; R. Davidii; R. Davidii var. elongata; R. Ecae; ${ }^{*}$ R. filipes; R. foliolosa; R. Gentiliana; R. Giraldii var. venulosa; ${ }^{*}$ R. glomerata; R. Helenae; R. Hugonis; R. jaluana; ${ }^{*} \mathrm{R}$. koreana; R. longicuspis; ${ }^{*} \mathrm{R}$. Lyonii var. alba; ${ }^{*} \mathrm{R}$. McDougalii; ${ }^{*}$ R. Macounii; ${ }^{*}$ R. Maximowicziana var. Jackii; ${ }^{*}$ R. Maximowicziana var. pilosa; R. Moyesii; R. Moyesii f. rosea; R. multibracteata; R. multiflora; ${ }^{*} \mathbf{R}$. multiflora var. cathayensis; ${ }^{*}$ R. Murielae; R. omeiensis; ${ }^{*} \mathbf{R}$. omeiensis var. chrysocarpa; R. omeiensis f. pteracantha; *R. Palmeri; R. persetosa; ${ }^{*}$ R. Prattii; ${ }^{*}$ R. pyrifera; R. Roxburghii var. hirtula; R. Roxburghii var. normalis; R. Rubus; R. saturata; R. sertata; R. setipoda; ${ }^{*}$. Spaldingii; R. spinosissima var. altaica; R. spinosissima "Dominic Sampson"; R. spinosissima "Iris"; R. spinosissima "Jupiter"; R. spinosissima "King of the Scots"; R. spinosissima "Plato"; R. spinosissima var. pusilla; R. spinosissima "Pythagoras"; *R. stellata var. mirifica; R. subserrulata; *R. suffulata; R. Sweginzowii; R. tuschetica; ${ }^{*} \mathrm{R}$. ultramontana; R. Wichuraiana; R. Willmottiae.

Rubus adenophorus; ${ }^{*} \mathbf{R}$. amabilis; ${ }^{*} \mathbf{R}$. amnicolus; R. Andrewsianus; R. arcticus; ${ }^{*} R$. arundelanus; $R$. aurantiacus; ${ }^{*} R$. biflorus var. quinqueflorus; *R. biformispinus; $R$. caesius var. turkestanicus; $R$. chroösepalus; R. corchorifolius; R. coreanus; $\mathbf{R}$. crataegifolius; $\mathbf{R}$. flagelliflorus; ${ }^{*} \mathbf{R}$. flosculosus; R. flosculosus f. parvifolius; R. Fockeanus; R. Gentilianus; R. geophilus; *R. Giraldianus; *R. glandicaulis; R. Henryi; R. hupehensis; R. ichangensis; R. innominatus; R. innominatus var. Kuntzeanus; R. inopertus; R. irenaeus; *R. Jeckylanus; *R. junceus; R. Koehneanus; R. Lambertianus; *R. lasiostylus var. dizygos; R. macilentus; R. melanolasius; $\mathbf{R}$. mesogaeus; ${ }^{*} \mathbf{R}$. multiformis; ${ }^{*} \times \mathbf{R}$. neglectus; ${ }^{*} \mathbf{R}$. orarius; R. Parkeri; R. parvifolius; ${ }^{*}$ R. peculiaris; R. platyphyllus; R. Playfairianus; ${ }^{*} \mathbf{R}$. plicatifolius; $\mathbf{R}$. pungens; ${ }^{*} \mathbf{R}$. recurvans; ${ }^{*} \mathrm{R}$. recurvicaulis; ${ }^{*} \mathbf{R}$. recurvicaulis var. inarmatus; $\mathbf{R}$. semierectus; $\mathbf{R}$. setchuenensis; ${ }^{*} \mathbf{R}$. setosus; ${ }^{*} \mathbf{R}$. spectabilis var. vernus; ${ }^{*} \mathbf{R}$. tardatus; $\mathbf{R}$. thibetanus; $\mathbf{R}$. trianthus; ${ }^{*} \mathbf{R}$. tricolor; $\mathbf{R}$. vicarius; $\mathbf{R}$. xanthocarpus. 
*Sabia latifolia; *S. Schumanniana.

*Sageretia pycnophylla.

*Salix Bockii; *S. cardiophylla; *S. cathayana; *S. eriocarpa; *S. Fargesii; *S. Gilgiana; *S. hypoleuca; *S. jessoensis; *S. koreensis; *S. macroblasta; *S. magnifica; *S. Matsudana; *S. moupinensis; *S. phanera; *S. purpurea var. multinervis; *S. Rehderiana; *S. subfragilis; *S. Wallichiana.

Sambucus canadensis f. maxima; *S. canadensis var. subtomentosa; S. microbotrys; S. melanocarpa; S. racemosa var. Sieboldiana; *S. Schweriniana.

*Sapindus Drummondii.

Sarcococca Hookeriana var. digyna; S. Hookeriana var. humilis; S. ruscifolia.

*Sargentodoxa cuneata.

*Sassafras randaiensis; S. tzumu.

Schizandra chinensis; *S. glaucescens; S. grandiflora; S. Henryi; S. nigra; S. propinqua var. sinensis; *S. rubriflora; *S. sphenanthera.

Schizophragma integrifolium; S. integrifolium var. molle.

Securinega fluggeoides; S. ramiflora.

Sibiraea laevigata var. angustata; S. tomentosa.

*Sinofranchetia chinensis.

Sinomenium acutum; S. acutum var cinereum.

*Sinowilsonia Henryi.

*Smilax discotis var. concolor; *S. longipes; *S. megalantha; *S. menispermoides; *S. scobinicaulis; *S. Sieboldii; *S. trachypoda; *S. vaginata.

Solanum Dulcamara var. chinense.

*Sophora affinis; S. japonica var. pyramidalis; S. japonica var. pubescens; *S. japonica var. vestita; S. viciifolia.

Sorbaria Aitchisonii; S. arborea; *S. arborea var. glabrata; *S. arborea var. subtomentosa; S. assurgens; S. stellipila.

$\times$ Sorbaronia Dippelii; XS. fallax; $\times$ S. heterophylla.

$X$ Sorbopyrus auricularis; $X S$. auricularis var. bulbiformis.

*Sorbus alnifolia; *S. alnifolia var. lobulata; *S. alnifolia var. submollis; S. angustifolia; S. Aria var. Decaisneana; S. caloneura; S. chamaemespilus; S. commixta; *S. commixta var. rufo-ferruginea; *S. Conradinae; S. discolor; *S. Esserteauiana; ${ }^{*}$ S. expansa; S. Folgneri; S. Folgneri var. pendula; S. Hostii; *S. hupehensis var. aperta; *S. japonica var. calocarpa; *S. Koehneana; ${ }^{*} \mathrm{~S}$. megalocarpa; ${ }^{*} \mathrm{~S}$. megalocarpa var. cuneata; *S. meliosmifolia; S. Mougeotii; *S. multijuga; *S. multijuga var. microdonta; *S. munda f. subarachnoidea; *S. munda f. tatsienensis; S. occidentalis; *S. pallescens; *S. plantierensis; S. pohuashanensis; *S. randaiensis; *S. Rehderiana; S. sambucifolia; *S. Sargentiana; *S. scalaris; S. scopulina; S. serotina; *S. setschwanensis; *S. unguiculata; S. Vilmorinii; S. Wilsonii; S. Zahlbruckneri.

Sphaeralcea remota. 
$\times$ Spiraea arguta; $\times$ S. assimilis; $\times$ S. blanda; S. bullata; S. calcicola; S. canescens; S. dahurica var. canescens; S. dasyantha; XS. Foxii; S. gemmata; S. Henryi; S. japonica var. acuminata; *S. japonica var. ovalifolia; *S. koreana; S. longigemmis; S. lucida; $\times \mathrm{S}$. macrostachya; XS. Margaritae; XS. microthyrsa; *S. Miyabei var. glabrata; *S. mollifolia; $\times$ S. mollis; $\times$ S. multiflora; S. myrtilloides; S. nipponica; $\times S$. notha; XS. nudiflora; *S. obtusa; XS. oxyodon; XS. pachystachya; $\times \mathrm{S}$. pikoviensis; S. prunifolia var. simpliciflora; S. pubescens; ${ }^{*} \times \mathrm{S}$. pyramidata; $\times \mathrm{S}$. revirescens; *S. Rosthornii; *S. Sargentiana; $\times \mathrm{S}$. Schinabeckii; $X$ S. semperflorens; $X$ S. superba; *S. sylvestris; $X S$. syringiflora; ${ }^{*} \mathrm{~S}$. trichocarpa; $\times \mathrm{S}$. tristis; ${ }^{*} \mathrm{~S}$. ulmifolia (Korean form); S. vaccinifolia; S. Veitchii; *S. virginiana var. serrulata; S. Wilsonii.

Spondias axillaris.

*Stachyurus chinensis; S. praecox.

*Staphylea Bolanderi; S. holocarpa; S. holocarpa var. rosea.

Stewartia monadelpha.

*Stranvaesia Davidiana; S. Davidiana var. undulata.

Styrax Hemsleyanus; *S. Shiraiana; *S. Veitchiorum; *S. Wilsonii.

Sycopsis sinensis.

XSymphoricarpos Chenaultii; *S. oreophilus; *S. sinensis.

*Syringa affinis; *S. dilatata; *S. formosissima; $\times S$. Henryi var. eximia; XS. Henryi var. Lutèce; S. Koehneana; *S. Komarowii; *S. Komarowii var. Sargentiana; *S. microphylla; *S. Palibiniana; *S. pinnatifolia; S. reflexa; *S. Rehderiana; S. Sweginzowii; S. tomentella; S. vulgaris (wild type); S. Wolfii.

*Taiwania cryptomerioides.

Tapiscia sinensis.

Taxus brevifolia (from Idaho and Montana); ${ }^{* T}$. chinensis.

Tetracentron sinense.

*Tetrastigma obtectum var. pilosum.

*Thuja koraiensis; T. plicata (hardy Idaho form); T. plicata var. nana.

*Thujopsis dolobrata var. Hondai.

Tilia caroliniana; ${ }^{* T}$. caroliniana var. rhoophila; T. floridana; ${ }^{*} \mathrm{~T}$. insularis; T. intonsa; ${ }^{*}$ T. Maximowicziana; T. Miqueliana; T. Oliveri; T. tuan; ${ }^{* T}$. tuan var. chinensis.

*Triosteum Fargesii.

*Tripetaleia bracteata; ${ }^{*}$ T. paniculata.

*Tripterygium Regelii.

Trochodendron aralioides.

*Tsuga caroliniana; T. chinensis; ${ }^{*}$ T. yunnanensis.

*Tsusiophyllum Tanakae.

Ulmus Bergmanniana; U. foliacea var. umbraculifera; *U. japonica; U. laciniata; *U. laciniata var. nikoensis; U. pumila var. pinnato-ramosa; *U. serotina; *U. Wilsoniana. 
Vaccinium Buergeri; V. ciliatum; *V. fragile; *V. hirsutum; V. hirtum var. Smallii; V. japonicum; V. membranaceum; ${ }^{*} V$. moupinense; ${ }^{*}$ V. praestans; V. scoparium; *V. urceolatum.

Viburnum betulifolium; V. bitchuense; *V. bracteatum; V. buddleifolium; ${ }^{*} \mathrm{~V}$. Canbyi; ${ }^{*} \mathrm{~V}$. cinnamomifolium; V. cylindricum; ${ }^{*} \mathrm{~V}$. dasyanthum; V. Davidii; V. erosum; ${ }^{*}$ V. erubescens var. Prattii; V. foetidum var. rectangulum; *V. furcatum; V. Henryi; V. hupehense; V. ichangense; *V. kansuense; V. lobophyllum; *V. lobophyllum var. flocculosum; *V. molle; V. mongolicum; V. phlebotrichum; V. propinquum; V. rhytidophyllum; V. Sargentii; *V. Sargentii f. flavum; V. shensianum; V. theiferum; *V. urceolatum; V. utile; V. Veitchii; ${ }^{*}$ V. Wilsonii; V. Wrightii.

Vitis amurensis; $\times V$. Baileyana; V. betulifolia; V. Coignetiae; V. Davidii; V. Davidii var. cyanocarpa; V. flexuosa; V. flexuosa var. parvifolia; V. pentagona; ${ }^{*}$. pentagona var. bellula; V. Piasezkii; V. pulchra; V. reticulata; ${ }^{*} \mathrm{~V}$. Thunbergii var. sinuata; V. vinifera (form cultivated at Peking).

Whipplea modesta.

*Xylosma racemosum var. pubescens.

Zanthoxylum alatum var. planispinum; Z. Bungei; Z. dissitum; *Z. Piasezkii; Z. piperitum; Z. setosum.

The following hybrid trees and shrubs have been made at the Arboretum or have appeared in it spontaneously:

\section{Roses}

Arnoldiana

Dawson

Farquhar

Ida

Lady Duncan

Minnie Dawson
Pauline Dawson

Jacksonii

Sargent

Seashell

W. C. Egan

Malus arnoldiana

Malus Dawsoniana

Prunus arnoldiana

Pterocarya Rehderiana

Pyrus congesta

Rhododendron Anneliesae

Rhod. obtusum v. arnoldianum

Sorbus arnoldiana

Viburnum Jackii

\section{HAWTHORNS.}

During the last twenty-three years special attention has been given at the Arboretum to the study and cultivation of North American Hawthorns. Previous to 1899 some twenty species and varieties only had been recognized by botanists, but in that year a number of the plants raised from 
seeds collected principally in Missouri in 1880 flowered and produced fruit, and showed characters so distinct from those of any of the described species that a critical study of the genus as it appears in North America seemed desirable. In carrying out this investigation specimens have been collected in every state of the United States and in every Province of the Dominion of Canada, and 4269 different lots of seeds have been planted at the Arboretum and some two hundred thousand plants have been raised. No less than 1056 species and varieties have been distinguished by botanists in these twenty-three years and of these 672 species and varieties have been described by the Director of the Arboretum.

The living collection of these trees and shrubs which are often conspicuous in spring and autumn from the beauty and abundance of their flowers and highly colored fruits now contains seven hundred and thirty-five species and varieties, and make one of the interesting features of the Arboretum. Thousands of these plants raised at the Arboretum have been distributed in this country and Europe; and nearly complete collections have been established in the parks of Rochester, New York, and in England.

\section{THE HERBARIUM}

The necessity of a collection of dried plants for the correct determination of the living collections and for successful dendrological studies was felt in the earliest days of the Arboretum, but it was not until 1878 that the beginning of an herbarium was made. In that year Mr. John Robinson of Salem came to the Arboretum as curator of the proposed herbarium and began to gather specimens for it. Four years later he was succeeded as curator by Mr. Charles E. Faxon who remained in general charge of the herbarium until his death in 1918. He was succeeded by Mr. Alfred Rehder who is now the curator. The herbarium, which is confined to specimens of trees, shrubs and suffrutescent plants, now contains two hundred thousand sheets and a large number of fruits. It is hoped that it will be extended until it contains a representative of every ligneous plant in the world from the Arctic Circle of the two hemispheres to the equator. The silvas now best represented in the herbarium are those of North America and eastern Asia. Plants, however, are found in it from all the continents, and from nearly every country, and the only regions botanically important which are not represented are Madagascar, New Caledonia and New Guinea.

The first important collections of North American plants were made in 1880 and 1881 by the Director and his assistants engaged in preparing for the general government a report on the forests and forest wealth of the United States. The study of North American trees and shrubs begun forty years ago has been steadily continued to the present time, and large quantities of material have been gathered for the herbarium in every part of the country by officers of the Arboretum and collectors employed for the purpose. The herbarium received its first Asiatic plants in 1892 when the 
Director brought back from Japan a collection of about one thousand specimens. It was later enriched by the specimens collected in Japan, northern China and Korea by Mr. J. G. Jack of the Arboretum staff, by Purdom, Meyer, Sargent and Hers in northern China, by Henry in western China, by the collections of E. H. Wilson in western China, Korea and the entire Japanese Empire of about 8500 specimens, by the specimens collected by C. Schneider in southwestern China, and by several collections of the plants of the Philippine Islands made under the direction of the Philippine Bureau of Science.

The herbarium contains several collections made from trees and shrubs cultivated in Europe. The most important of them were made by $\mathrm{Mr}$. George Nicholson in the Royal Gardens at Kew, by Dr. C. Naudin at the Villa Thuret at Antibes in France, by A. Rehder and C. Schneider chiefly in Germany, and by H. Zabel of Muenden, Germany, containing the types of the numerous species, varieties and hybrids published by him.

The attempt has been made in the Arboretum herbarium to show in the case of important trees the varieties and range of the species, and from one hundred to three hundred sheets are occasionally devoted to the illustration of a single species and its varieties; in the case of trees like Oaks and Hickories the sheets are accompanied by many bottles of nuts.

The Pinaceae is the family best represented in the Arboretum herbarium. All the genera and all the species of this Family are represented with the exception of six Araucarias from New Caledonia, two species of Callitris and three species of Agathis from northern Australia, one Juniper from San Domingo and another from the Azores. Many of the species are represented by long series of specimens and by enough cones to show the range of their variation.

The herbarium contains the types of nearly all the new Chinese species published by the Arboretum in Plantae Wilsonianae, the new species published in Garden and Forest, in Trees and Shrubs, and in the Journal of the Arnold Arboretum, and of the new species and varieties of Crataegus, Carya, Quercus, Tilia, Aesculus and other genera published by the Director.

In its early years the office of the Arboretum and the herbarium and Library were established in a house in Brookline controlled by the Director, but in $1892 \mathrm{Mr}$. Horatio Hollis Hunnewell, a constant and devoted friend to the Arboretum, as have been his sons, furnished the money for the brick building near the Jamaica Plain entrance, and late in that year the offices for administration, the herbarium and the library were moved into it. This building also contains a collection of specimens of the wood and bark of most of the trees of the United States, a gift with the cases in which they are arranged of the late Morris K. Jesup of New York. In 1905 a fireproof four-storied wing was added to the Administration Building to contain the herbarium which is now arranged in steel cases extending to the ceiling of the low-studded and well lighted rooms conveniently arranged for the study of the specimens. 


\section{THE LIBRARY}

The Library of the Arboretum now contains 35,500 bound volumes and 8000 pamphlets. It was begun in 1873 when the Director bought for his own use a few books needed for the arrangement of the future Arboretum. This small library was gradually increased and when a few years later it was determined to prepare at the Arboretum an account of the trees of North America additional works on dendrology and descriptive botany essential to the production of that work were obtained by him. In 1892 the six thousand volumes which had by that time been accumulated were presented by the Director to the University, accommodations for a library having at that time been provided by the Arboretum.

The Arboretum Library contains the books in all editions and languages devoted to the description of trees. Its collection of Floras partly devoted to trees and monographs of genera in which trees and shrubs are described, is a large one. The collections of books and papers descriptive and cultural of various groups of plants like Conifers, Rosa, Rhododendron, Crataegus, Quercus, Salix, etc., are as nearly complete as it has been possible to make them. A complete collection of the works of Linnaeus is found in the Library; and it is believed that outside the walls of the British Museum there is not a more complete collection of the books relating to plants published in the fifteenth and sixteenth centuries. The collection of books of travel in which occur descriptions of trees or aspects of vegetation is a large and interesting one and contains a few rare volumes. Little attention has been paid to books relating to the description and care of the fruit trees usually cultivated in cold countries, for such works on pomology are found in libraries devoted to horticulture. There are, however, a large number of books relating to the history and cultivation of trees and shrubs valued for special products like tea, coffee, cocoa, oranges and their allies, cinchona, olives and the mulberry in its relation to the manufacture of silk as it has seemed desirable that this library should contain all books relating to woody plants with the exception of those which are more valuable in a purely horticultural library. There is not a complete collection of books on forestry in the Arboretum library, although it contains much that has been written on this subject especially that which is descriptive of the early efforts at forest management in the United States and Europe. Only a few books on paleobotany, vegetable pathology, physiology and entomology are now found in it. Its rapid growth in directions of more immediate importance in the arrangement and study of the collections of living plants has made it impossible to devote to these subjects the attention their importance demands. Such books will in time find a place in the library intended to furnish the best possible opportunity for the study of trees. The library is fortunate in the possession of a large number of complete sets of rare periodicals including two hundred which are now discontinued; it receives regularly the numbers of three hundred serials more or less devoted to trees and their cultivation. 
In 1904 Miss Ethelyn M. Tucker joined the staff of the Arboretum to assist in the care of the library and to prepare a Catalogue of its contents. In 1918 she was appointed Librarian. The books in the library have been systematically arranged by her under the system usually followed in American libraries and are fully and completely catalogued. When Miss Tucker began in 1904 to prepare the manuscript for a printed Catalogue the library contained 10,000 volumes; when the first volume of the catalogue was printed in 1914 the number had increased to 30,000 . The printed catalogue is contained in two quarto volumes. The first, which is devoted to periodicals and to authors and titles, contains 782 two-column pages, and in the second volume, which appeared in 1917 contains 542 two-column pages, the books are arranged according to subjects.

Early in the formation of the library it became evident that to build up a dendrological library and to carry on at the Arboretum a critical study of trees and other woody plants more information about the literature of trees than could be found in any printed bibliography was necessary. To meet this difficulty a plan was carefully worked out for a bibliography to contain a reference to every book, every magazine article and every paper in the Transactions of Learned Societies relating to trees or shrubs in all languages published before the end of the nineteenth century. This work was entrusted to Mr. Alfred Rehder, at that time assistant in the Herbarium, who began work on it in March 1900, and devoted his time to it until the printing of the last volume was finished. During the preparation of this book Mr. Rehder visited every library in the eastern United States in which botanical or horticultural books are found, and during two visits in Europe extending over a period of twenty-seven months studied in the botanical libraries of Great Britain, France, Spain, Denmark, Norway, Sweden, Germany, Austria, Italy and Russia. The name of this work is the Bradley Bibliography as it was partly paid for from the income of a gift made in 1897 to the Arboretum by Miss Abby A. Bradley of Hingham as a memorial to her father William Lambert Bradley. The first two volumes devoted to an enumeration of works on Dendrology, were issued in 1911, and in 1912. Volume iii. devoted to Arboriculture and the Economic Properties of Woody Plants appeared in 1915; volume iv. containing an enumeration of works on Forestry, in 1914, and the fifth and final volume, which contains the Index of Authors and Titles and a subject Index of the whole work, in 1918. The five volumes of the Bradley Bibliography contain rather more than one hundred thousand titles of books and papers relating to trees and shrubs printed on three thousand seven hundred and eighty-nine two-column quarto pages.

Other works prepared in the Library and Herbarium and published by the Arboretum are,-

The Pines of Mexico (1909) and a monograph of the Genus Pinus (1914) by Mr. George R. Shaw; The Plantae Wilsonianae (in 3 vol. 1913-17), being an account of the plants collected in western China by $\mathrm{E}$. H. Wilson 
for the Arboretum; The Cherries of Japan (1916) by Mr. Wilson; The Conifers and Taxads of Japan (1916) by Mr. Wilson; A Monograph of Azaleas by Messrs. Wilson and Rehder (1921); twelve volumes of the Bulletin of Popular Information (1911-22); the first three volumes of the Journal of the Arnold Arboretum (1919-22); and an illustrated Guide to the Arnold Arboretum (1911) with a second edition in 1921.

The following are some of the works which have been prepared by the Director in this library but were not published by the Arboretum: Report on the Forests of North America, being the ninth volume of the Final Reports of the Tenth Census of the United States (1884); The Woods of the United States with an account of their structure, qualities and uses (1885); The Silva of North America in fourteen volumes with seven hundred and forty plates (1891-1902); Trees and Shrubs; illustrations of new or little known ligneous plants, prepared chiefly from material at the Arnold Arboretum (1905-1913), largely by officers of the Arboretum. The ten volumes of Garden and Forest, a journal of horticulture, landscape art and forestry (1887-1897), were edited in the Arboretum library, in which Mr. Alfred Rehder has prepared the descriptions of a large part of the trees and shrubs included in Bailey's Cyclopedia of American Horticulture and in the second edition of that work, The Standard Cyclopedia of Horticulture.

\section{PHOTOGRAPHS}

The Arboretum collection of photographs now contains nine thousand six hundred pictures of trees and shrubs, types of vegetation, gardens and scenery. The photographs are mounted on cards $113 / 4$ inches long and $91 / 2$ inches wide and are arranged systematically in steel drawers. The two thousand eight hundred pictures made by Wilson in eastern Asia and Australasia form the most valuable and interesting part of this collection. The Arboretum photographs have been carefully catalogued by Miss Tucker and can be easily and quickly examined. This collection proves to be an important and useful addition to both the Library and Herbarium.

\section{EDUCATION}

The Arboretum in the conception of its managers is a museum founded and carried on to increase the knowledge of trees. This they have endeavored to do by a collection of living plants arranged for convenient examination and study, by the distribution of surplus material obtained in the Arboretum explorations, and by the publication of the results of the dendrological investigations carried on in its laboratories. That they have been at least partly successful is shown by the standing of the Arboretum in the estimation of the men in different countries best able to judge of its usefulness.

No attempt has been made to give instruction at the Arboretum to 
classes of University undergraduates. A few special students, often in recent years from China and Japan, are received by Professor J. G. Jack who for many years now has given field lessons during the spring and autumn months among the collections of trees. In the answers to the letters which come to the Arboretum, as to all museums, asking for information, help and instruction are freely given.

The Arnold Arboretum is not a School of Forestry or of Landscape Gardening. It is a station for the study of trees as individuals in their scientific relations, economic properties and cultural requirements and possibilities. On the information gathered in museums like the Arnold Arboretum successful silviculture and landscape gardening are dependent, for silviculture is the cultivation on a large scale of the trees most valuable in a particular locality, and landscape gardening demands a knowledge of the individual plants which can be naturally associated for the decoration of parks and gardens.

No account of the Arnold Arboretum is complete without mention of two remarkable men who have died in its services.

Charles Edward Faxon, one of three brothers who devoted the best part of their lives to the study of Natural History, was born in 1846 in Jamaica Plain where he died in 1918. As a boy he had begun to study the New England flora and to show his ability to draw by his copies in color of Audubon's pictures of birds. Before 1870 he had made most of the colored drawings to illustrate Eaton's "Ferns of North America"; and from 1879 to $\mathbf{1 8 8 4}$ he was instructor in botany at the Bussey Institution. In 1882 when the plan was made to prepare at the Arboretum an illustrated work on the trees of North America Faxon was invited to make the drawings for it. At this time he took charge of the herbarium and library which he continued to manage until his death. His knowledge of botany, especially of the flora of eastern North America, his love of books and his remarkable faculty for learning foreign languages were of great value in the organization and care of these departments. During twenty-one years Faxon was engaged on the seven hundred and forty-four drawings which illustrate the "Silva of North America," and during his twenty-six years of service for the Arboretum nineteen hundred and twenty-four of his drawings of plants were published. To his work he brought enthusiasm, industry, good taste, a thorough understanding and love of his subjects, an unusually skilful pencil, and skill in microscopic analysis. No other American botanical artist has had his experience and industry, and no one has contributed more to the reputation of the Arboretum and the value of its publications.

JACKsON T. DAwson was the first superintendent of the Arboretum and continued to fill this position and that of propagator until his death in the summer of 1916. Born in the East Riding of Yorkshire in 1841 Dawson was brought when a child to this country by his mother and when eight years old was started in gardening in an uncle's nursery in Andover, Massachusetts. He served for three years in a Massachusetts regiment during 
the Civil War and was several times wounded. On his discharge from service in 1864. Dawson entered the employ of Hovey \& Company of Cambridge, at that time one of the important commercial nurseries of the United States. In 1871 he was made head gardener of the School of Horticulture at the Bussey Institution by Francis Parkman, the first professor of that department in the School, a position which he filled for three years when he became superintendent of the Arboretum. Dawson had the real love for plants and an exceptional knowledge of them. As a plant propagator it is not possible that any one could have been his superior. No problem in propagation was ever too difficult for him to solve. At the Arboretum he was compelled to work in crowded quarters with insufficient appliances, and in spite of this handicap he raised for the Arboretum during his forty-two years of service probably more than a million plants, and there are now few public or private gardens in the northern hemisphere which have not been enriched by his labors. Dawson served the Arboretum faithfully and made many friends for it; and without his assistance it would have been impossible to make the collections of living plants what they are today.

\section{FUTURE NEEDS}

During its first fifty years the area occupied by the Arboretum has been increased from one hundred and twenty-five to two hundred and fifty acres. The endowment has been increased from $\$ 103,847.57$ to $\$ 808,175.75$, and a construction fund of $\$ 129,257$ immediately available for improvements has been accumulated.

The greatest collection of the hardy trees and shrubs of the northern hemisphere has been made and arranged, and many new plants largely discovered through its explorations have been distributed.

It has established the largest and most important herbarium in the world devoted exclusively to preserving the records of trees and shrubs, and a library which within the limits of its special subjects is not surpassed. More important than these are the friendly relations it has established with the students and cultivators of trees in all parts of the world, for through these relations it will be able to increase and extend its usefulness.

In discussing the future of the Arboretum and its needs it must be remembered that during its first half century it has been managed not merely as a New England museum but as a national and international institution working to increase knowledge of trees in all parts of the world and as anxious to help a student in Tasmania or New Caledonia as in Massachusetts. An institution with such ambitions must be equipped to answer any question about any tree growing in any part of the world which may be addressed to it. During the first fifty years of the Arnold Arboretum only the foundations of such an establishment have been laid, but in laying these foundations some of the needs of the future are made clear. These are, - 
First: The collection of more information about the trees in many parts of the world than can now be found here. Such information can be obtained only in small part by correspondence and the information which the Arboretum needs can only be successfully obtained by agents sent out to obtain it. It is desirable that the work which the Arboretum has begun in eastern continental Asia should be continued and if possible completed. The flora of the coastal region north of latitude 45, including Kamtschatka, is still very imperfectly known. From this region trees and shrubs, still unknown in gardens, which will grow in New England can probably be obtained. Explorations in the northern part of Kansu, the great northwest province of China, may also be expected to enrich northern gardens. The flora of China south of the Yang-tze-kiang River and east of the Poyang Lake is still little known; and the trees of Cochinchina (Tonkin, Annam and Siam) are still badly represented in the Arboretum herbarium; and Harvard College will not have fulfilled its agreement with the Arnold Trustees until it has caused to be explored through the Arboretum the forests which cover the ranges of the Altai Mountains which form the southern boundary of central Siberia and the great interior region south of these mountains.

If the Arboretum is to become a great institution for gathering and spreading information about trees and allied plants specimens and a series of photographs of every species of tree in the world should be found in its herbarium. The work which it has accomplished in its first fifty years in North America and the Japanese Empire should be extended over the rest of the world. For the trees of the tropics this is now important as tropical forests are fast disappearing to make room for plantations of rubber-producing and other economic plants. The best soil is selected for these plantations, and as with few exceptions the largest and best individuals of a species are produced in the best soil, many species, or certainly their best representatives, must disappear, and in the future the student of trees must depend for any knowledge of many trees on the material and information preserved in institutions like the Arnold Arboretum. The exploration of the tropical forests of the world will require perhaps a century and a large expenditure of money to accomplish. It is work that this Arboretum should begin and steadily push forward.

Second: The Arboretum requires a properly equipped department for the study of the diseases of trees in this country and in other parts of the world.

Third: The Arboretum requires a department in which the study of insects dangerous to trees and the methods for their control can be carried on in connection with the other investigations undertaken by the Arboretum and controlled by it.

Fourth: The Arboretum needs a department for the breeding of new races of plants. The world already owes much to the intelligence and skill of the plant breeder. He has increased the value of many farm crops and has 
produced shrubs which are the chief ornament of many gardens. Less has been done in attempting to improve trees by the mixing of different species. Hybrid trees especially among Oaks often occur in this country. Several of these trees are already in this Arboretum where they grow more rapidly and are often hardier than their parents. Natural hybrids of Poplar-trees are common and often grow more rapidly than their parents; and a number of hybrid Poplars have been raised artificially in Europe and promise to become valuable trees. One of the largest, hardiest and most rapid-growing of all Elm-trees is a natural hybrid between two European species. The best Hickory-nuts are produced by trees which are natural hybrids; and one of the largest and handsomest hybrid Oak-trees in the United States has also been artificially reproduced by crossing the two species which were the parents of the natural hybrid. Judging by what little is now known about hybrid trees it does not seem improbable that new races of trees may be produced artificially which will contribute materially to the value of the forest products of the world and increase the beauty of parks and gardens. The Arnold Arboretum with its great collections and its connection with the principal cultivators of plants is now the best place for breeding new trees and shrubs in the United States. Plant breeders from all parts of the country send to it for the material needed in their work but this work can best be done here.

Fifth: A Rose Garden and a Rock Garden if planned comprehensively would add much to the horticultural value of the Arboretum, and bring many visitors to it.

Only a larger endowment is needed to make possible these Arboretum activities and extensions. 




\section{UNIVERSITY OF CALIFORNIA LIBRARY}

BERKELEY

Return to desk from which borrowed.

This book is DUE on the last date stamped below.

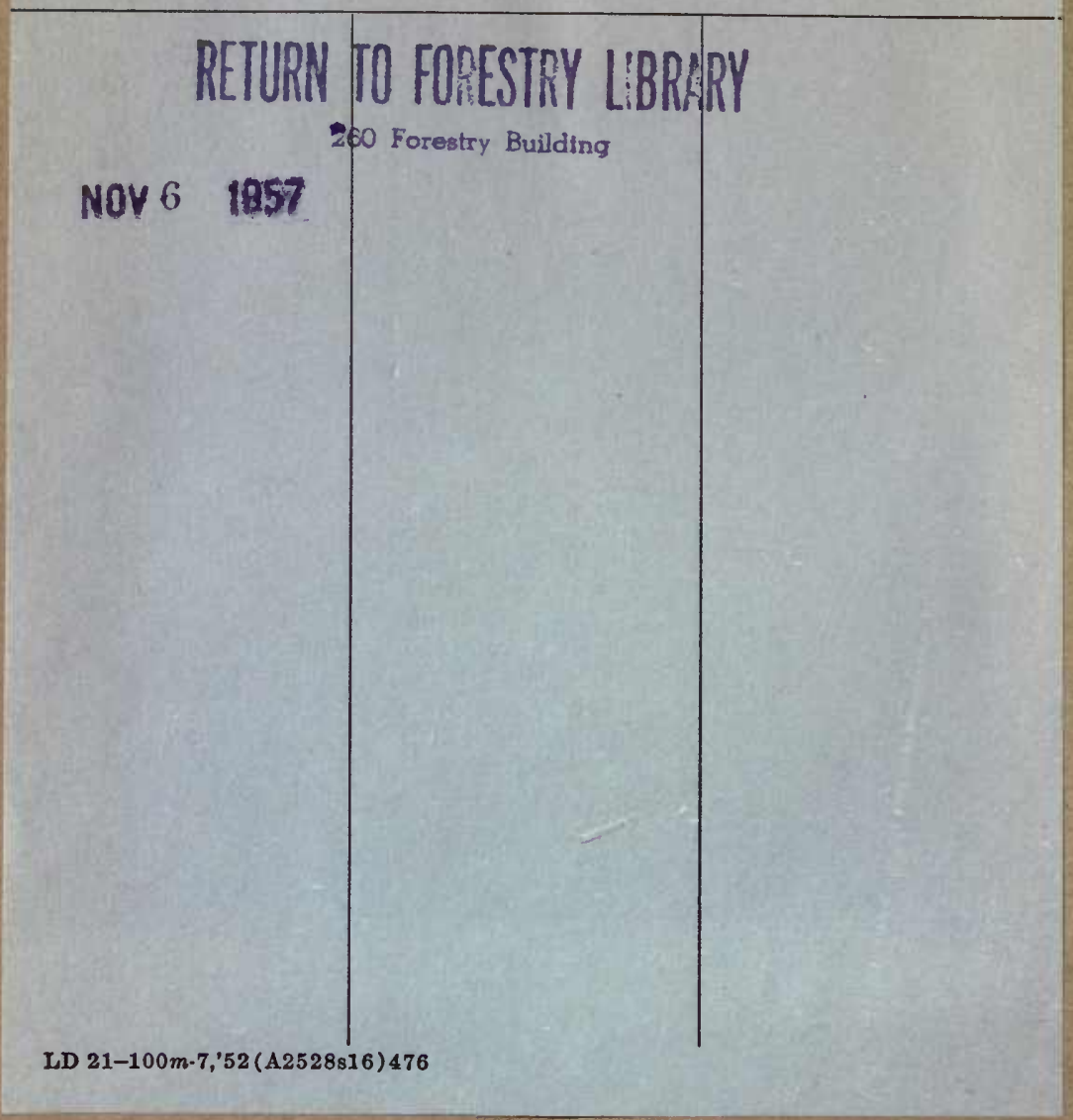


